\title{
Non-Coding RNAs as Prognostic Markers for Endometrial Cancer
}

\author{
Roberto Piergentili ${ }^{1,+}{ }^{\mathbb{D}}$, Simona Zaami ${ }^{2, *}++^{\mathbb{D}}$, Anna Franca Cavaliere ${ }^{3}$, Fabrizio Signore ${ }^{4}$, Giovanni Scambia ${ }^{5,6}$, \\ Alberto Mattei ${ }^{7}$, Enrico Marinelli ${ }^{8}$, Caterina Gulia ${ }^{9}$ and Federica Perelli ${ }^{7}$
}

1 Institute of Molecular Biology and Pathology, Italian National Research Council (CNR-IBPM), 00185 Rome, Italy; roberto.piergentili@cnr.it

2 Department of Anatomical, Histological, Forensic and Orthopedic Sciences, "Sapienza" University of Rome, Viale Regina Elena 336, 00161 Rome, Italy

3 Gynecology and Obstetric Department, Azienda USL Toscana Centro, Santo Stefano Hospital, 59100 Prato, Italy; annafranca.cavaliere@uslcentro.toscana.it

4 Obstetrics and Gynecology Department, USL Roma2, Sant'Eugenio Hospital, 00144 Rome, Italy; fabrizio.signore@aslroma2.it

5 Fondazione Policlinico Universitario A. Gemelli IRCCS, Gynecologic Oncology Unit, 00168 Rome, Italy; giovanni.scambia@policlinicogemelli.it

6 Universita' Cattolica Del Sacro Cuore, 00168 Rome, Italy

7 Gynecology and Obstetric Department, Azienda USL Toscana Centro, Santa Maria Annunziata Hospital, 50012 Florence, Italy; alberto.mattei@uslcentro.toscana.it (A.M.); federica.perelli@uslcentro.toscana.it (F.P.)

8 Unit of Forensic Toxicology (UoFT), Department of Anatomical, Histological, Forensic and Orthopedic Sciences, Sapienza University, 00161 Rome, Italy; enrico.marinelli@uniroma1.it

9 Department of Urology, Misericordia Hospital, 58100 Grosseto, Italy; 85cate@live.it

* Correspondence: simona.zaami@uniroma1.it; Tel.: +39-327-3385-804

+ These authors contributed equally to this work.

Citation: Piergentili, R.; Zaami, S.; Cavaliere, A.F.; Signore, F.; Scambia, G.; Mattei, A.; Marinelli, E.; Gulia, C.; Perelli, F. Non-Coding RNAs as Prognostic Markers for Endometrial Cancer. Int. J. Mol. Sci. 2021, 22, 3151 https://doi.org/10.3390/ijms22063151

Academic Editor: Konrad Huppi

Received: 5 February 2021

Accepted: 12 March 2021

Published: 19 March 2021

Publisher's Note: MDPI stays neutral with regard to jurisdictional claims in published maps and institutional affiliations.

\begin{abstract}
Endometrial cancer (EC) has been classified over the years, for prognostic and therapeutic purposes. In recent years, classification systems have been emerging not only based on EC clinical and pathological characteristics but also on its genetic and epigenetic features. Noncoding RNAs (ncRNAs) are emerging as promising markers in several cancer types, including EC, for which their prognostic value is currently under investigation and will likely integrate the present prognostic tools based on protein coding genes. This review aims to underline the importance of the genetic and epigenetic events in the EC tumorigenesis, by expounding upon the prognostic role of ncRNAs.
\end{abstract}

Keywords: endometrial cancer; molecular biology; non-coding RNA; biomarkers; prognostic factors

\section{Introduction}

Endometrial cancer (EC) is the most widespread gynecological tumor in developed countries. Its incidence is around seventy-nine cases per 100,000 women in Europe, with the average age at the time of diagnosis being sixty-two years $[1,2]$.

Well-established risk factors have been identified: Lynch Syndrome and Cowden Syndrome genetic predisposition, polycystic ovary syndrome (PCOS), tamoxifen use, infertility, diabetes and obesity [3,4].

About one-third of patients have localized disease at the time of its first identification [1]. The prognosis for EC patients with early stage tumor (stages I and II) is mostly favorable. Currently, the treatment of patients with initial disease relies on risk factors reported within the European Society for Medical Oncology (ESMO), European Society of Gynaecological Oncology (ESGO), European SocieTy for Radiotherapy \& Oncology (ESTRO) consensus published in 2016. Most of them can be submitted to surgery alone or followed by vaginal brachytherapy (BRT) or external beam radiation therapy (EBRT), adding platinum-based therapy in stage I high-risk and stage II patients [5].

The five-year overall survival (OS) is strictly stage-related, with a $95 \%$ OS for stage I women and $69 \%$ for stage II [1]. Nevertheless, some patients classified as low-risk have a 
relapse [6]. Patients affected by recurrent and advanced cancer (stage III or IV) have a poor prognosis, with a five-year OS related to metastatic disease between 15 to $17 \%$ [1]. This subset of patients is generally submitted to carboplatin and paclitaxel-based chemotherapy [5].

Prognostic factors for EC useful for management are represented by patient's clinicalpathologic factors like age, stage, grading, and lymphovascular space invasion, and lymphovascular space invasion (LVSI).

Traditionally, EC has been divided in two pathogenetic groups, according to the Bokhman's dualistic theory: endometrioid (Type 1) and non-endometrioid cancers (Type 2) [7]. Nearly $80 \%$ of EC type I patients had lower grade tumors, whereas $20 \%$ had high grade tumors [7]. The former are typically associated to a good prognosis, show high estrogen and progesterone receptors expression, and rarely get LVSI [7], while the latter are associated with poor prognosis, prevalence of high grade, low progesterone sensitivity, and high potential for LVSI [7].

Recently, The Cancer Genome Atlas (TCGA) described four EC groups based on genetic features: polymerase epsilon (POLE) mutated, hypermutated secondary to microsatellite instability (MSI), low copy number, and high copy number [8].

The current stratification of clinical-pathological risk implies that a significant percentage of patients are still too much or undertreated, with a large proportion of patients in the initial stage demonstrating distant metastases and some intermediate-risk patients who must undergo adjuvant therapies, to prevent a relapse, that will take only in a few cases [9].

For this reason, the trial "Post-Operative Radiation Therapy in Endometrial Carcinoma" (PORTEC)-4a is ongoing to define additional precise management strategies of early stage EC, by fostering the integration of molecular and clinical-pathological factors [10]. The authors defined three groups, according to their corresponding prognosis: (i) favorable, patients with POLE or microsatellite stable (MSS), p53 wild type (WT), and CTNNB1 WT; (ii) intermediate, patients with MSS, p53 WT, and CTNNB1 mutation; and (iii) unfavorable, patients with p53 mutation or $>10 \%$ L1CAM expression [10].

Non-coding RNAs (ncRNAs) are constituted by transcripts of nucleotides with very little or no protein-coding capability. Their expression patterns in many malignant tumors consist of alterations which can promote or suppress tumorigenesis and cancer progression. They can regulate protein-coding organic phenomenon at epigenetic, transcriptional, posttranscriptional, and alternative levels [11].

Evidence shows that the anomalous expression of ncRNAs is associated to the prevalence, development, and prognosis of many cancers, and that they can be used as prognostic markers to guide the risk stratification of EC patients [12].

This review aims to summarize the genetic factors on which the current prognostic systems are based and to indicate the pathogenetic and the prognostic role of the ncRNAs, for the purpose of better defining tailored treatments and oncological surveillance on each EC patient.

\section{The Genetics of EC}

Recently, research has been focusing on the genetic characterization of human neoplasms, to better define prognosis and tailored therapies. EC represents one of the main tumors on which it has surfaced that genetic mutations and epigenetic modifications are the foundation of tumorigenesis. This is on account of its high incidence within the population and the discovery of prognostic factors that enable sound clinical management.

\subsection{TCGA Classification}

In 2013, the TCGA Research Network published, in Nature, the article titled "Integrated genomic characterization of endometrial carcinoma". The authors performed a genomic and proteomic analysis of $373 \mathrm{EC}$ and provided a diagnostic classification supporting the tumor's molecular biology [8]. 
They defined four subtypes of EC according to genomic characteristics. Their molecular analysis showed that about $25 \%$ of G3 endometrioid EC have a molecular constitution like serous EC. The similarities between endometrioid and serous tumors led the authors to stated that genomic-based classification could result in improving management of EC patients, assuming the tendency to treat tumors with copy-number alterations with chemotherapy rather than radiation alone [8].

The authors reported four prognostic categories, as follows:

(1) POLE ultramutated

This group has the most favorable prognosis and a longer progression-free survival. It is associated with endometrioid histotype.

It shows alterations of specific genes: POLE, PTEN, PIK3R1, PIK3CA, FBXW7, KRAS, and TP53 [13].

The POLE gene encodes the subunit A of DNA polymerase epsilon, which is involved in DNA replication and repair [14]. In EC patients, the most common mutations registered in POLE were P286R and V411L respectively in exon nine and exon thirteen [15].

(2) Microsatellite instability hypermutated

This group is characterized by intermediate prognosis.

It is associated with endometrioid histotype.

It shows alterations of specific genes: PTEN, KRAS, and ARID1A [13].

MSI represents the phenotypic evidence that DNA mismatch repair (MMR) is not functioning normally. MMR deficiency is linked to many cancers such as brain, colon and endometrial. There are four MMR genes (MLH1, MSH2, MSH6, or PMS2) whose inactivation leads to mutations accumulations called MSI. It can occur through several mechanisms: insertions, deletions, point mutations, loss of heterozygosity, copy number changes, structural rearrangements, and methylation of a gene promoter [16].

(3) Copy-number low

This group is characterized by intermediate prognosis.

It is associated to endometrioid histotype.

It shows alterations of specific genes: CTNNB1 and PTEN [13].

Copy number changes are included within the genome structural variation: They comprise duplication or deletion events that have an effect a considerable number of DNA base pairs.

(4) Copy-number high

This group is characterized by unfavorable prognosis.

It is associated with serous histotype.

It shows alterations of specific genes: TP53, FBXW7, and PPP2R1A [13].

High copy variety changes are related to cancer-related genomic instability and fast growth progression and invasion.

\subsection{PORTEC-4a Classification}

The PORTEC-4a is an ongoing trial which is based on molecular risk profiles in EC women. It is focused on the comparison between a molecular-based treatment versus standard adjuvant treatment in early stage EC patients.

It aims to compare the standard treatment according to current international guidelines to the experimental treatment based on genetic risk factors in patients with early stage EC. The actual standard treatment hinges on vaginal BRT, which entails internal radiation of the vaginal vault, using a vaginal cylinder.

Patients are randomized to one of the two arms: molecular profile-based group (experimental one) versus standard recommendations group (the active comparator one). Patients randomized to the molecular profile-based group are followed for vaginal recurrence after surgery, if classified as (i) "favorable molecular risk profile"; they are treated with vaginal BRT, if classified as (ii) "intermediate molecular risk profile"; finally, they are treated with 
EBRT, if classified as (iii) "unfavorable molecular risk profile". The primary endpoint of the trial is the vaginal recurrence while the secondary endpoints are occurrence of adverse events, patient quality of life, site of recurrence, progression-free survival, overall survival, and EC-related healthcare costs [10].

The authors reported three prognostic categories as follows:

(1) Favorable:

POLE mutation or No Specific Molecular Profile (NSMP) while not CTNNB1 mutations.

(2) Intermediate:

Mismatch repair-deficient (MMRd) or NSMP with CTNNB1 mutations.

(3) Unfavorable:

LVSI TP53 abnormal immunohistochemical staining or L1CAM overexpression.

CTNNB1 gene encodes beta-catenin protein, which affects cell growth, differentiation and motility. Its mutation is related to carcinogenesis in several tumors depending on the Wnt signaling pathway and is related to EC favorable prognosis [17].

P53 gene encodes for the tumor suppressor p53 protein (TP53) mainly involved in the cell-cycle checkpoints regulation and DNA repair, preserving genomic stability from different type of damages, including senescence and apoptosis; it is altered in many neoplasms [18].

TP53 abnormal immunohistochemical staining is related to EC poor prognosis: Loss of tumor suppressor p53 would lead to a high degree of genomic instability and fast cancer progression and invasion.

L1CAM is a transmembrane protein belonging to the gamma globulin family, which can promote aggressive tumor biology. It has a role in metastasis formation regulating cells migration, invasion, and proliferation [19]. It is associated with more aggressive EC histologies, advanced stage, LVSI, and recurrence [20].

\section{The Epigenetics of EC}

According to online databases such as UniProt, the human genome harbors approximately 20.3 thousand protein-coding genes. However, its length is ca. 3.2 billion base pairs per haploid genome, indicating that the vast majority of the human DNA currently has no known function [21,22]. Thus, in the last decades, ever greater importance has been attributed to the non-protein-coding portion of the genome, and on how it controls several aspects of the cell homeostasis.

As a general rule, with the term "epigenetics" scientists refer to a set of gene function alterations that are mostly mediated either by the action of non-coding RNAs (ncRNA) that may control the half-life and/or the translation of target mRNA, or by structural DNA modifications (such as DNA methylation or histone modifications) mostly impairing DNA transcription; in both cases, although the DNA sequence is not altered, these modifications are inheritable [23]. It is now widely accepted that these phenomena play a pivotal role in cancer etiopathogenesis and, in many instances, they have a high diagnostic and prognostic value $[24,25]$. This is true also for EC, for which both mechanisms have been amply described in the literature [11,26-31].

\section{1. ncRNA Role in EC Etiology}

As for ncRNA, a major classification is made on the basis of their length. Those longer than approximately 200 nucleotides (nt) are called long ncRNA (lncRNA), while the others, that usually span only a few tens of nucleotides (mostly ca. 20-25 nt long), are collectively called short ncRNA (sncRNA). Still, both classes are made up of very heterogeneous molecules in length, function or structure [32]. For example, sncRNA of 20-30 nt include siRNA, miR and piRNA, with different biogenesis and function; on the other hand, YRNA, T-UCR, circRNA, snRNA and snoRNA span lengths of 20-1600 nt, thus partly overlapping sncRNA length with the same degree of heterogeneity in their biology. Consequently, this 
"structural" classification may not be the most adequate categorization for these molecules. However, due to their widespread use, we will still rely on it in our dissertation, and in this specific case we will refer to lncRNA as to $100+$ nt molecules, and to sncRNA as to microRNA (miR).

An analysis of the PubMed database, using the search string "endometrial cancer AND ncRNA", retrieves almost 750 articles to date. Interestingly, in the time frame from January 2018 to January 2021, the search allows to collect around 250 articles, making up roughly $33 \%$ of the total. This means that over the past few years EC research focused on these molecules has grown quite considerably, which reflects their enormous potential in the characterization of this tumor. These studies report that, in EC, these molecules are either up- or down-regulated compared to controls and according to their role as oncogenes or oncosuppressors, either if they promote or inhibit cancer growth and survival, respectively. Overall, it is not always possible to define a given ncRNA (and this is especially true for $\mathrm{miR}$ ) as either a pure oncogene or as an oncosuppressor, because their targets may vary according to tissue type or stage of development; therefore, it is not infrequent to find that one ncRNA - and especially miR-is up-regulated in one cancer and down-regulated in another one. To further complicate this scenario, even inside the same tumor it is possible to find apparently contradictory results, that in some instances may be explained by the different system used (cell culture vs. biopsy specimen, samples showing different tumor staging, and so on). Consequently, the need to better understand the identity and behavior of each of these molecules is pivotal in understanding EC etiology.

An overview of the mechanisms of action of ncRNA in human cells is summarized in Figure 1. The action of a sncRNA is usually quite straightforward (Figure 1A): It has the capability to bind a target mRNA—usually, its $3^{\prime}$ UTR end - through sequence homology and to inhibit its function, either by promoting mRNA degradation or by impairing its translation. As such, sncRNA that inhibit the action of oncogenes are functionally oncosuppressors, and vice versa. Instead, the function of lncRNAs is usually more complex. In some instances, it involves the binding of a sncRNA, thus creating a ceRNA couple (see next section). However, additional genetic control pathways had been described to date, involving the interplay with the DNA double helix either directly (to change its shape and promote regulatory proteins recruitment) (Figure 1B) or indirectly (through interaction with histone modifiers such as HDACs). In those cases, lncRNAs may bind specific proteins causing DNA bending thanks to their interaction with other DNA binding proteins. This promotes their proximity and, in turn, the formation an active complex, able to locally influence DNA transcription. This influence may either enhance or inhibit gene transcription, depending on the DNA regions and proteins involved. Another possible mechanism some lncRNA use to control gene expression is to directly inhibiting target mRNA translation through antisense annealing (Figure 1C).

As a consequence, their target gene(s) (when known) is/are deregulated as well. Several groups focused on the identification of these ncRNAs, either using deep sequencing from EC samples, or by using a bioinformatics approach, allowing the identification of hundreds of putative candidates $[12,26,27,31]$ that are either up- or down-regulated in the considered samples. In such cases, future works will have to figure out whether this deregulation is merely a consequence of an altered tumor cell metabolism, or whether it is causally related to carcinogenesis. According to available databases, there are more than 60 lncRNAs and over $120 \mathrm{miRs}$ deregulated in EC, for which a molecular and/or functional characterization is available, which has shed a light on their possible role as EC biomarkers and possibly, even as therapeutic targets. An overview of the current state of affairs in that regard has been outlined in Table 1 (lncRNA) and Table 2 (miR). Excerpts of these Tables are reported in Table 3, in which we list ncRNAs interacting with genes identified by TCGA or PORTEC4a classifications (see Section 2) and important for EC diagnosis and prognosis. 

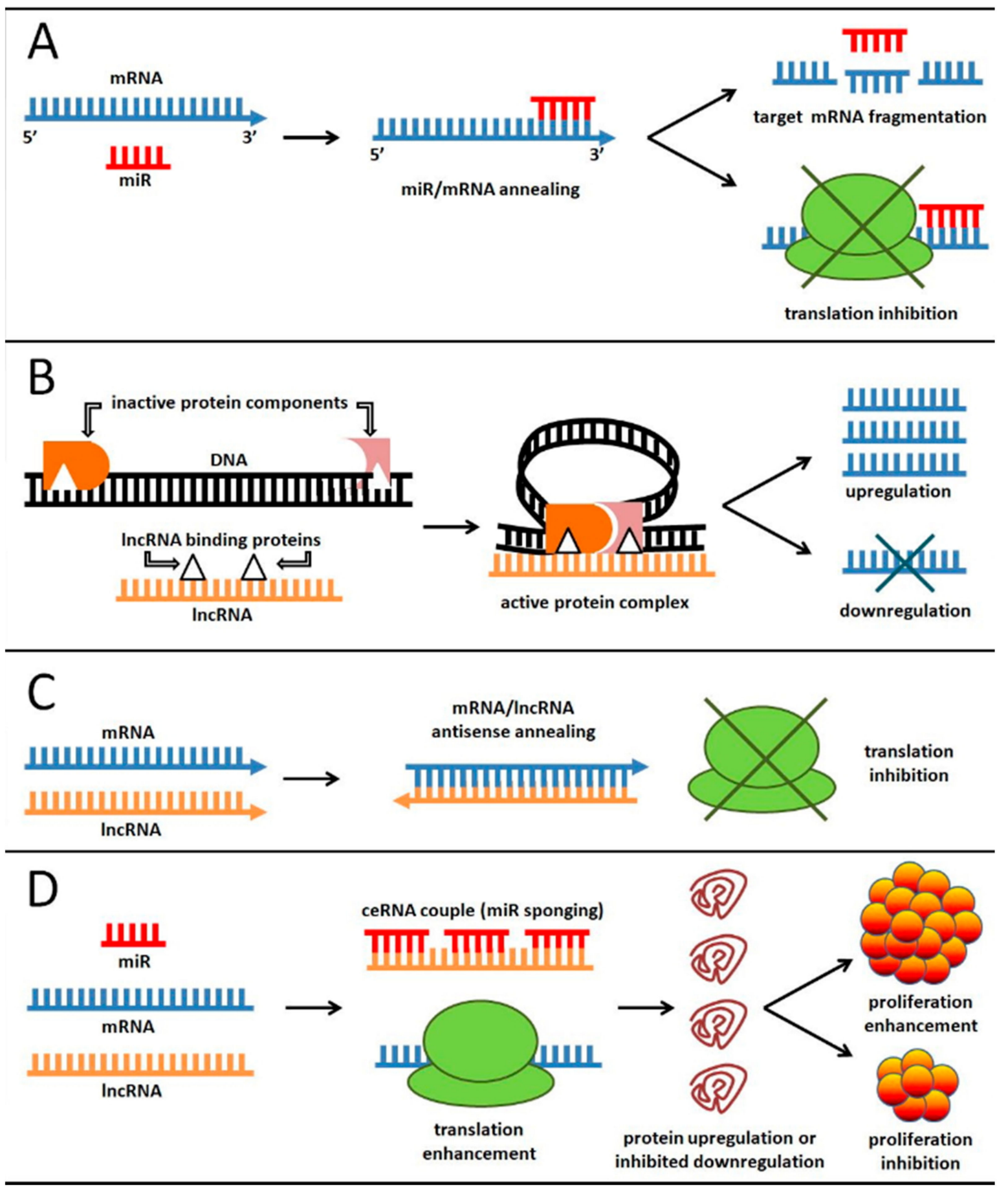

Figure 1. Schematic representation of the most common ncRNA functions in cells. In all panels, the target genes may be either oncogenes or oncosuppressors, depending on the ncRNA involved and the mRNA target; as such, any of the described mechanisms may enhance or inhibit cell proliferation. (A): miR-mediated post-transcriptional control of gene expression; miR can pair with target mRNA through sequence homology and promote either mRNA fragmentation or translation impairment. (B): gene expression control of lncRNA through DNA structure modification; in this case gene expression is regulated at the transcriptional level. (C): gene expression control of lncRNA through antisense annealing; in this case gene expression is regulated at the post-transcriptional level. (D): lncRNA and mRNA compete for the miR binding; in this case the lncRNA may sponge the miR(s) and allow mRNA translation. See text for additional explanations. Blue, mRNA; red, miR (sncRNA); orange, lncRNA; black, DNA; green, ribosome; other colors/forms, proteins. List of abbreviations: sncRNA is short non coding RNA; miR is micro RNA; lncRNA is long non coding RNA; ceRNA is competing endogenous RNA; mRNA is messenger RNA. 
Table 1. A summary of lncRNAs that play a role in endometrial cancer (EC) pathogenesis and for which a functional characterization is available.

\begin{tabular}{|c|c|c|c|c|c|}
\hline $\begin{array}{l}\text { Long non Coding } \\
\text { RNA Name }\end{array}$ & $\begin{array}{l}\text { Expression } \\
\text { Level }\end{array}$ & $\begin{array}{l}\text { Described } \\
\text { Functions }\end{array}$ & miR Interactions & $\begin{array}{l}\text { Other Functional Interactions } \\
\text { in EC }\end{array}$ & References \\
\hline ABHD11-AS1 & up & $a, b$ & & $\begin{array}{c}\text { cyclin D1, CDK1, CDK2, CDK4, } \\
\text { Bcl-xl, VEGFA,p16 }\end{array}$ & [33] \\
\hline AL161431.1 & up & $\mathrm{a}$ & miR-1252-5p & MAPK & [34] \\
\hline ASlnc04080 & up & $a, b$ & & at least 19 genes & [35] \\
\hline BANCR & up & $\mathrm{b}$ & & MMP1/2, ERK, MAPK & {$[36]$} \\
\hline C2orf48 & up & $\mathrm{n} / \mathrm{a}$ & miR-183 & CCNB1 & [37] \\
\hline CARLo-5 & up & $a, c$ & & $\mathrm{CDK}, \mathrm{MMP} 2 / 9$ & [38] \\
\hline CCAT1 & up & $\mathrm{n} / \mathrm{a}$ & miR-181a-5p & & {$[39,40]$} \\
\hline CCAT2 & up & $a, c$ & $\mathrm{miR}-216 \mathrm{~b}$ & Bcl-2 & [41] \\
\hline CDKN2B-AS & up & $\mathrm{d}$ & miR-125a-5p & Bcl-2, MRP4 & [42] \\
\hline CHL1-AS1 & up & $\mathrm{n} / \mathrm{a}$ & miR-6076 & CHL1 & [43] \\
\hline circ_0002577 & up & $a, b, e$ & miR-197 & CTNND1 & {$[44,45]$} \\
\hline circ_0061140 & up/down & $\mathrm{a}$ & miR-149-5p & STAT3 & [46] \\
\hline DANCR & up & $\mathrm{b}$ & miR-214 & & [47] \\
\hline DCST1-AS1 & down & c & miR-92a-3p & Notch1 & [48] \\
\hline DLEU1 & up & $b, e$ & miR-490 & $\begin{array}{c}\text { Bcl-2, BAX, E-cadherin, } \\
\text { N-cadherin, Snail, vimentin, } \\
\text { CASP-3, SP1, PI3K, AKT1, } \\
\text { p70S6K, rpS6, GSK3B, STAT3, } \\
\text { Bcl-xl, mTOR }\end{array}$ & {$[49,50]$} \\
\hline FER1L4 & down & c & & PTEN, AKT & {$[51,52]$} \\
\hline FRMD6-AS2 & down & $a, c$ & & FRMD6 & [53] \\
\hline GAS5 & down & $\mathrm{b}$ & $\begin{array}{l}\text { miR-103, } \\
\text { miR-222-3p }\end{array}$ & p27, PTEN & {$[54,55]$} \\
\hline H19 & up & $a, b, c, e$ & $\begin{array}{l}\text { miR-20b-5p, } \\
\text { miR-124-3p, } \\
\text { miR-612 }\end{array}$ & $\begin{array}{l}\text { HIF-1 } \alpha, \text { AXL, PCNA, Snail, } \\
\text { HOXA10, E-cadherin, ITGB3 }\end{array}$ & [56-61] \\
\hline HAND2-AS1 & down & c & & NMU & [62] \\
\hline HOTAIR & up/down & $b, f$ & miR-646 & $\begin{array}{l}\text { PRB, NPM1, Beclin-1, MDR, } \\
\text { P-gp, PTEN, PI3K }\end{array}$ & [63-68] \\
\hline HOTAIRM1 & up & $\mathrm{a}, \mathrm{c}, \mathrm{e}$ & & HOXA1 & [69] \\
\hline HOXB-AS1 & up & $a, c$ & miR-149-3p & $\begin{array}{l}\text { Wnt10b, } \beta \text {-catenin, cyclin D1, } \\
\text { c-Myc }\end{array}$ & [70] \\
\hline LA16c-313D11.11 & down & $a, c$ & miR-205-5p & PTEN, PI3K & [71] \\
\hline LINC00261 & down & $a, c$ & $\begin{array}{l}\text { miR-27a, miR-96, } \\
\text { miR-153, miR-182, } \\
\text { miR-183 }\end{array}$ & FOXO1 & [72] \\
\hline LINC00483 & up & $\mathrm{b}$ & miR-183, miR-192 & CCNB1, GRHL1 & [37] \\
\hline LINC00672 & down & $\mathrm{d}$ & & p53, LASP1 & [73] \\
\hline LINC00958 & up & c & miR-761 & DOLPP1 & [74] \\
\hline LINC01016 & up & $\mathrm{n} / \mathrm{a}$ & $\begin{array}{l}\text { miR-302a-3p, } \\
\text { miR-3130-3p }\end{array}$ & NFYA, SATB1 & [75] \\
\hline
\end{tabular}


Table 1. Cont.

\begin{tabular}{|c|c|c|c|c|c|}
\hline $\begin{array}{l}\text { Long non Coding } \\
\text { RNA Name }\end{array}$ & $\begin{array}{l}\text { Expression } \\
\text { Level }\end{array}$ & $\begin{array}{l}\text { Described } \\
\text { Functions }\end{array}$ & miR Interactions & $\begin{array}{l}\text { Other Functional Interactions } \\
\text { in EC }\end{array}$ & References \\
\hline LINC01170 & up & $\mathrm{b}$ & & AKT & [76] \\
\hline LINC01220 & up & $a, b$ & & MAPK11 & [77] \\
\hline LINC01410 & up & $\mathrm{a}, \mathrm{b}$ & $\operatorname{miR}-23 c$ & CHD7 & [78] \\
\hline LINC-ROR & up & $\mathrm{n} / \mathrm{a}$ & miR-145 & & [79] \\
\hline LINP1 & up & $\mathrm{a}, \mathrm{c}$ & & PI3K, AKT & [80] \\
\hline lnc-NA & down & $\mathrm{a}, \mathrm{b}$ & & NR4A1 & [81] \\
\hline lnc-OC1 & up & $\mathrm{b}$ & miR-34a & PD-L1 & [82] \\
\hline lncRNA-ATB & up & $a, b, e$ & miR-126 & CASP-3, Sox2, TGF-b, PIK3R2 & [83] \\
\hline lncRNA-HEIH & up & $\mathrm{a}, \mathrm{d}$ & & MAPK & [84] \\
\hline lnc-XLEC1 & down & $\mathrm{n} / \mathrm{a}$ & & MBP-1 & [85] \\
\hline LOC134466 & down & $\mathrm{b}$ & $\operatorname{miR}-196 a-5 p$ & TAC1 & [86] \\
\hline LOXL1-AS1 & up & $\mathrm{a}, \mathrm{b}$ & $\operatorname{miR}-28-5 p$ & RAP1B & [87] \\
\hline MALAT1 & down & $c, \mathrm{e}$ & miR-200c & TGF-B & [88] \\
\hline MEG3 & down & $a, f$ & & PI3K, MEG3, Notch1, Hes1 & {$[89,90]$} \\
\hline miR143HG & down & $\mathrm{b}$ & miR-125a & p53 & [91] \\
\hline MIR22HG & down & $a, b$ & $\operatorname{miR}-141-3 p$ & DAPK1 & [92] \\
\hline NEAT1 & up & a & $\begin{array}{l}\text { miR-361, } \\
\text { miR-144-3p, } \\
\text { miR-146b-5p }\end{array}$ & $\begin{array}{l}\text { MEF2D, ROCK1, WNT7A, } \\
\text { VEGFA, PDE4B, EZH2, STAT3, } \\
\text { KPNA4, LEF1, MMP9, c-Myc }\end{array}$ & [93-95] \\
\hline NIFK-AS1 & down & a & miR-146a & & [96] \\
\hline NR2F1-AS1 & up & $a, b, c$ & $\operatorname{miR}-363$ & SOX4, PI3K, AKT & [97] \\
\hline PCAT1 & up & $a, b, c, e$ & & $\begin{array}{c}\text { E-cadherin, EZH2, Bcl-2, } \\
\text { vimentin, N-cadherin, Bad }\end{array}$ & {$[98,99]$} \\
\hline PCGEM1 & up & $a, c, b$ & miR-129-5p & $\begin{array}{c}\text { STAT3, Bcl-2, survivin, VEGFA, } \\
\text { MMP2 }\end{array}$ & [100] \\
\hline PVT1 & up/down & $a, b$ & miR-195-5p & UPF1, FGFR1, FGF2 & {$[101,102]$} \\
\hline RNA-14327.1 & up & $\mathrm{a}, \mathrm{e}$ & & Kca3.1 & [103] \\
\hline RP11-357H14.17 & up & $\mathrm{n} / \mathrm{a}$ & $\begin{array}{l}\text { miR-24-1-5p, } \\
\text { miR-27b, miR-143, } \\
\text { miR-204, miR-503, } \\
\text { miR-4770 }\end{array}$ & up to 183 targets & [104] \\
\hline RP11-395G23.3 & down & a, c & miR-205-5p & PTEN, AKT & [105] \\
\hline RP11-89K21.1 & up & $\mathrm{n} / \mathrm{a}$ & $\begin{array}{c}\text { miR-27b, miR-4770, } \\
\text { miR-143, miR-204, } \\
\text { miR-125a-5p, } \\
\text { miR-125b-5p, } \\
\text { miR-139-5p, } \\
\text { miR-670-3p }\end{array}$ & up to 183 targets & [104] \\
\hline SNHG16 & up & a & miR-490-3p & HK2 & [106] \\
\hline SNHG5 & down & a, c & $\operatorname{miR}-25-3 p$ & BTG2 & [107] \\
\hline SNHG8 & up & a & $\operatorname{miR}-152$ & c-MET & [108] \\
\hline SRA & up & $a, b, e$ & & EIF4E-BP1, Wnt, $\beta$-catenin & [109] \\
\hline
\end{tabular}


Table 1. Cont.

\begin{tabular}{cccccc}
\hline $\begin{array}{c}\text { Long non Coding } \\
\text { RNA Name }\end{array}$ & $\begin{array}{c}\text { Expression } \\
\text { Level }\end{array}$ & $\begin{array}{c}\text { Described } \\
\text { Functions }\end{array}$ & miR Interactions & $\begin{array}{c}\text { Other Functional Interactions } \\
\text { in EC }\end{array}$ & References \\
\hline TDRG1 & up & $\mathrm{a}, \mathrm{b}, \mathrm{c}$ & $\mathrm{VEGFA,} \mathrm{AKT,} \mathrm{PI3K,} \mathrm{mTOR}$ & [110,111] \\
\hline TUG1 & up & $\mathrm{n} / \mathrm{a}$ & $\begin{array}{c}\text { miR-34a-5p, } \\
\text { miR-299 }\end{array}$ & SOCS4 & [112] \\
\hline TUSC7 & down & a, e & miR-23b, miR-616 & ZNRD1 & [113,114] \\
\hline ZNRD1-AS1 & up & n/a & & {$[115]$} \\
\hline
\end{tabular}

Note: IncRNAs are listed in alphabetical order (Column 1) and for each we report its expression in EC compared to control (Column 2) (either up- or down-regulated), its role in the development of EC (Column 3) and its functional interactions with target genes in EC (Columns 4 and 5), as reported in the available literature (Column 6). In the case of no data being available, we report " $n / a$ ". In Column 3, the following abbreviations are used: a, cell growth; b, apoptosis; c, cell invasion/migration; d, drug resistance; e, EMT transition; f, other. The interactions with miR are highlighted in Column 4, because in those cases the lnc/snc couple acts as ceRNA (see text for further explanations), while in Column 5 we report the protein coding genes. As for the latter targets, for simplicity, we pooled together both up- and down-regulated genes, as both are "deregulated" in EC compared to controls; we included all proteins cited in the respective references, even if their regulation is not a direct effect of the ncRNA. Data in the table are mostly retrieved from http:/ / www.bio-bigdata.com/lnc2cancer / (accessed on 13 January 2021) and updated according to the most recent (1/2018-onward) data available in PubMed (http:/ / pubmed.ncbi.nlm.nih.gov/; last accession: 28 January 2021). Notes: (i) data about lncRNA CTBP1-AS2 are not included, because the article was retracted, due to ethical issues; (ii) data about lncRNA OGFRP1 are not included, because the article was retracted, due to methodological issues; (iii) data about lncRNA HOTTIP are not included because the article was retracted, with no explanation available.

Table 2. A summary of sncRNAs that play a role in EC pathogenesis and for which a functional characterization is available.

\begin{tabular}{|c|c|c|c|c|c|}
\hline miR Name & Expression Level & Described Functions & Primary Targets & Secondary Targets & References \\
\hline miR-101 & down & $a, b, c, f$ & $\begin{array}{c}\text { EZH2, MCL-1, } \\
\text { FOS, mTOR, } \\
\text { COX-2 }\end{array}$ & $\begin{array}{l}\text { VEGF-A, TSP-1, COX-2, } \\
\text { PGE2, P450arom }\end{array}$ & [116-118] \\
\hline miR-101-3p & down & $\mathrm{f}$ & EZH2 & & [119] \\
\hline miR-103 & up & $\mathrm{a}$ & $\mathrm{ZO}-1$ & & [120] \\
\hline miR-106a & up & $a, b, c$ & MYC, BCL2L11 & p21, BIM & {$[121,122]$} \\
\hline miR-106b & up/down & $a, b$ & PTEN & AKT, mTOR & {$[123,124]$} \\
\hline miR-107-5p & up & $\mathrm{a}, \mathrm{c}$ & $\mathrm{ER} \alpha$ & & [125] \\
\hline $\mathrm{miR}-10 \mathrm{~b}$ & up & $a, b, c$ & HOXB3 & & [126] \\
\hline miR-1271 & down & $a, c, b$ & CDK1, LDHA & & {$[127,128]$} \\
\hline miR-130b & down & e & ZEB1 & & [129] \\
\hline miR-134 & down & $a, c$ & POGLUT1, Notch & & [130] \\
\hline miR-137 & down & a & EZH2, LSD1 & & [131] \\
\hline miR-139-5p & down & a, c & HOXA10 & & [132] \\
\hline miR-142 & down & a & CCND1 & Ki67 & [133] \\
\hline miR-143 & down & $a, c, f$ & DNMT3B, MAPK1 & & {$[134,135]$} \\
\hline miR-145 & down & $\mathrm{f}$ & DNMT3B, OCT4 & & {$[134,136]$} \\
\hline miR-145-5p & down & $a, c, b$ & DUSP6 & & [137] \\
\hline miR-148b & down & $a, c, e, f$ & ERMP1, DNMT1 & HIF-1, Nrf2 & {$[138,139]$} \\
\hline miR-152 & down & $a, b, f$ & $\begin{array}{c}\text { DNMT1, E2F3, } \\
\text { MET, Rictor, SOS2, } \\
\text { NRAS, APC, } \\
\text { PIK3R3, SOS1, } \\
\text { PTEN, CDC25B }\end{array}$ & & [140-142] \\
\hline miR-155 & up & a & AGTR1 & & [143] \\
\hline
\end{tabular}


Table 2. Cont.

\begin{tabular}{|c|c|c|c|c|c|}
\hline miR Name & Expression Level & Described Functions & Primary Targets & Secondary Targets & References \\
\hline miR-15a-5p & down & $\mathrm{a}$ & WNT3A & & [144] \\
\hline miR-181c & down & $\mathrm{b}$ & PTEN, NOTCH2 & $\begin{array}{c}\text { Bax, Bcl-2, AKT, p53, } \\
\text { Cyclin D. }\end{array}$ & {$[145,146]$} \\
\hline $\operatorname{miR}-181 d$ & up & $a, b, f$ & $\begin{array}{l}\text { PIK3R3, SOS1, } \\
\text { PTEN }\end{array}$ & & [141] \\
\hline miR-182 & up & a & TCEAL7 & c-Myc, cyclin D1, NFkB & [147] \\
\hline miR-183 & up & $a, b, c, e$ & MMP9, CPEB1 & E-cadherin, vimentin & {$[148,149]$} \\
\hline miR-183-5p & down & $a, b, c, e$ & Ezrin & & [150] \\
\hline miR-184 & down & c & CDC25A & NOTCH1/2/3/4, HES1 & [151] \\
\hline miR-191 & up & a & TET1 & & {$[152]$} \\
\hline miR-195 & down & $c, e$ & SOX4, GPER & $\begin{array}{c}\text { TIMP-2, MMP2/9, PI3K, } \\
\text { AKT }\end{array}$ & {$[153,154]$} \\
\hline miR-200a & up & e & FOXA2 & E-cadherin, vimentin & [155] \\
\hline miR-200b & up & c & TIMP2 & MMP2 & [156] \\
\hline miR-200c & up & $\mathrm{a}, \mathrm{c}, \mathrm{e}$ & $\begin{array}{l}\text { BRD7, BMI-1, } \\
\text { PTEN, PTENP1 }\end{array}$ & $\begin{array}{c}\beta \text {-catenin, cyclinD1, } \\
\text { c-myc, AKT, Slug, } \\
\text { N-cadherin, PI3K, } \\
\text { E-cadherin }\end{array}$ & [157-159] \\
\hline miR-202 & down & $c, e$ & FGF2 & $\begin{array}{l}\beta \text {-catenin, } \mathrm{N} \text {-cadherin, } \\
\text { vimentin, } \mathrm{E} \text {-cadherin }\end{array}$ & [160] \\
\hline miR-204 & down & a, c & FOXC1 & & [161] \\
\hline miR204-5p & down & $\mathrm{a}, \mathrm{c}$ & $\begin{array}{c}\text { TrkB, SF3B1, } \\
\text { FBXW7, BRD4 }\end{array}$ & & {$[162,163]$} \\
\hline miR-205 & up & $a, b, c, e$ & $\begin{array}{l}\text { ESRRG, PTEN, } \\
\text { AKT } \\
\end{array}$ & E-cadherin, Snail & [164-168] \\
\hline miR-206 & down & a, c & HDAC6 & PTEN, AKT & [169] \\
\hline miR-21-5p & up & $\mathrm{e}$ & SOX17 & & {$[170]$} \\
\hline miR-215 & up & a, c, d, e & LEFTY2 & & [171] \\
\hline miR-218 & down & c & ADD2 & & {$[172]$} \\
\hline miR-222-3p & up & $a, c, d$ & $\mathrm{ER} \alpha$ & & [173] \\
\hline miR-223 & down & a & IGF-1R & & {$[174]$} \\
\hline $\operatorname{miR}-25$ & up & $a, b$ & $\mathrm{p} 21, \mathrm{BIM}$ & & [121] \\
\hline $\operatorname{miR}-26 a$ & down & $\mathrm{e}$ & $\mathrm{EZH} 2$ & $\begin{array}{l}\text { N-cadherin, Vimentin, } \\
\text { Snail, E-cadherin }\end{array}$ & [175] \\
\hline miR-27a-5p & up & c & SMAD4 & & [176] \\
\hline $\operatorname{miR}-27 b-3 p$ & down & c & MARCH7 & $\begin{array}{l}\text { Snail, Vimentin, } \\
\text { E-cadherin }\end{array}$ & [177] \\
\hline miR-29a-5p & down & $a, c, b$ & TPX2 & & [178] \\
\hline $\mathrm{miR}-29 \mathrm{~b}$ & down & $a, c, d$ & PTEN & $\mathrm{BAX}, \mathrm{Bcl}-2, \mathrm{AKT}$ & [179] \\
\hline $\operatorname{miR}-29 b$ & down & $\mathrm{f}$ & VEGFA & $\begin{array}{c}\text { MAPK, PI3K, mTOR, } \\
\text { Bcl-2 }\end{array}$ & [180] \\
\hline $\operatorname{miR}-29 c-3 p$ & down & $\mathrm{d}$ & KDM5B & & [181] \\
\hline miR-301b & down & e & ZEB1 & & [129] \\
\hline miR-302a-5p & down & c & HMGA2 & & [182] \\
\hline $\mathrm{miR}-30 \mathrm{c}$ & down & $a, c$ & MTA1 & mTOR, 4E-BP1, AKT & [183-185] \\
\hline
\end{tabular}


Table 2. Cont.

\begin{tabular}{|c|c|c|c|c|c|}
\hline miR Name & Expression Level & Described Functions & Primary Targets & Secondary Targets & References \\
\hline miR-320a & down & $\mathrm{a}, \mathrm{c}, \mathrm{e}$ & eIF4E, IGF-1R & MMP3, MMP9, TGF- $\beta 1$ & {$[186,187]$} \\
\hline $\operatorname{miR}-326$ & down & $a, c, e, f$ & GPR91, TWIST1 & STAT3, VEGF & {$[188,189]$} \\
\hline miR-335 & up & a & RBM10 & Numb-L & [190] \\
\hline $\operatorname{miR}-340$ & down & $a, b$ & $\begin{array}{l}\text { p27, KIP1, Bax, } \\
\text { Casp3 }\end{array}$ & & [191] \\
\hline miR-340-5p & down & $\mathrm{c}, \mathrm{e}$ & eIF4E & MMP3, MMP9, TGF- $\beta 1$ & [186] \\
\hline miR-34a & down & $\mathrm{a}, \mathrm{c}, \mathrm{e}$ & $\begin{array}{l}\text { L1CAM, p16, } \\
\text { Ki-67, Notch1 }\end{array}$ & & [192-194] \\
\hline $\mathrm{miR}-34 \mathrm{c}$ & down & $a, b, c, d$ & E2F3 & & {$[195,196]$} \\
\hline miR-367-3p & down & c & HMGA2 & & [182] \\
\hline miR-372 & down & $\mathrm{a}, \mathrm{c}$ & $\begin{array}{l}\text { RhoC, Cyclin A1, } \\
\text { CDK2 }\end{array}$ & $\begin{array}{c}\text { MMP2, MMP9, PARP, } \\
\text { Bax }\end{array}$ & [197] \\
\hline $\operatorname{miR}-373$ & up & $\mathrm{a}, \mathrm{c}, \mathrm{e}$ & LATS2 & Wnt & [198] \\
\hline miR-381 & down & a, c & IGF-1R & AKT, ERK & [199] \\
\hline $\operatorname{miR}-409$ & down & a & Smad2 & & [200] \\
\hline $\operatorname{miR}-424$ & down & $a, b, e$ & $\begin{array}{l}\text { E2F7, GPER, } \\
\text { IGF-1R, CPEB2 }\end{array}$ & $\begin{array}{l}\text { PI3K, AKT, E-cadherin, } \\
\text { vimentin }\end{array}$ & [201-204] \\
\hline $\operatorname{miR}-449 a$ & down & $a, b, c$ & $\begin{array}{l}\text { CDC25A, NDRG1, } \\
\text { SRC }\end{array}$ & PTEN, AKT, ERK1/2 & [205-207] \\
\hline miR-494-3p & up & $a, c$ & PTEN & PI3K, AKT & [208] \\
\hline $\operatorname{miR}-495$ & down & $a, b, f$ & $\begin{array}{l}\text { GSK3B, NRAS, } \\
\text { TCF4, PIK3CB, } \\
\text { PIK3R3, CCND1, } \\
\text { AXIN2, PIK3R1, } \\
\text { SOS1, PIK3CA, } \\
\text { FOXO3, PTEN }\end{array}$ & $\begin{array}{l}\text { Bcl-2, VEGF, Bax, } \\
\text { CASP-3 }\end{array}$ & {$[141,209]$} \\
\hline miR-505 & down & a & TGF- $\alpha$ & $\begin{array}{l}\text { MMP2, MMP9, CDK2, } \\
\text { Bax, PARP }\end{array}$ & [210] \\
\hline miR-522 & up & a, c & MAOB & & [211] \\
\hline miR-543 & down & a, c & FAK, TWIST1 & & [212] \\
\hline miR-589-5p & down & $a, c$ & TRIP6 & $\begin{array}{c}\text { E-cadherin, } \mathrm{N} \text {-cadherin, } \\
\text { vimentin }\end{array}$ & [213] \\
\hline miR-652 & up & $\mathrm{a}, \mathrm{c}$ & RORA & $\beta$-catenin & [214] \\
\hline $\operatorname{miR}-93$ & up & $a, b, e, f$ & p21, BIM, FOXA1 & $\begin{array}{l}\text { E-cadherin, N-cadherin, } \\
\text { MAPK1, RBBP7, Smad7 }\end{array}$ & {$[121,215,216]$} \\
\hline miR-93-5p & up & $\mathrm{a}, \mathrm{c}$ & IFNR1 & STAT3, MMP9 & [217] \\
\hline miR-940 & up & $\mathrm{a}, \mathrm{c}$ & MRVI1 & & [218] \\
\hline miR-944 & up & a & CADM2 & & [219] \\
\hline miR-99a & down & $a, b, c$ & AKT1, mTOR & & [220] \\
\hline
\end{tabular}

Note: sncRNA (miR) already cited in Table 1 are omitted from this list. miR are listed according to increasing identification number (Column 1) and for each we report its expression in EC compared to control (Column 2) (either up- or down-regulated), its role in the development of EC (Column 3) and its functional interactions with primary and secondary target genes in EC (Columns 4 and 5) as reported in the available literature (Column 6). In the case of no data being available, we report " $\mathrm{n} / \mathrm{a}$ ". In Column 3, the following abbreviations are used: a, cell growth; b, apoptosis; c, cell invasion/migration; d, drug resistance; e, EMT transition; f, other. In Column 4, primary targets are the genes whose function is directly controlled by the miR in EC, while in Column 5 secondary targets are those genes whose function in EC is influenced by the action of primary targets. For simplicity, we pooled together all targets independently of their up- or down-regulation, as all are "deregulated" in EC compared to controls; we included all deregulated proteins cited in their respective reference(s) (Column 6). Data in the table are primarily retrieved from http:/ / mircancer.ecu.edu/ (accessed on 15 January 2021) and updated according to the most recent (1/2018-onward) data available in PubMed (http:/ / pubmed.ncbi.nlm.nih.gov/; last access: 28 January 2021). 
Table 3. ncRNA which functionally interact with EC diagnostic and prognostic genes.

\begin{tabular}{|c|c|c|}
\hline $\begin{array}{c}\text { Gene (TGCA/PORTEC4a } \\
\text { Classifications) }\end{array}$ & Interacting lncRNA & Interacting sncRNA \\
\hline CTNNB1 ( $\beta$ catenin) & HOXB-AS1, SRA & miR-200c, miR-202, miR-652 \\
\hline FBXW7 & $\mathrm{n} / \mathrm{a}$ & miR-204-5p \\
\hline L1CAM & $\mathrm{n} / \mathrm{a}$ & miR-34a \\
\hline PIK3CA & $\mathrm{n} / \mathrm{a}$ & miR-495 \\
\hline PIK3R1 & $\mathrm{n} / \mathrm{a}$ & miR-495 \\
\hline PTEN & $\begin{array}{c}\text { FER1L4, GAS5, HOTAIR, } \\
\text { LA16c 313D11.11, } \\
\text { RP11-395G23.3 }\end{array}$ & $\begin{array}{l}\text { mir-106b, miR-152, miR-181c, } \\
\text { miR-181d, miR-200c, miR-205, } \\
\text { miR-29b, miR-494-3p, miR-495 }\end{array}$ \\
\hline TP53 & LINC00672, miR143HG & $\mathrm{n} / \mathrm{a}$ \\
\hline $\begin{array}{l}\text { ARID1A, KRAS, MLH1, } \\
\text { MLH2, MLH6, PMS2, } \\
\text { POLE, PPP2R1A }\end{array}$ & unknown & unknown \\
\hline \multicolumn{3}{|c|}{$\begin{array}{l}\text { Note: Reported genes are those indicated as diagnostic/prognostic markers in either TCGA or PORTEC4a } \\
\text { classification, they are listed in alphabetical order (Column 1). ncRNAs are divided in long (Column 2) and short } \\
\text { (Column 3) ncRNA. In Column 3, only miR which directly interact with the target gene (Column 1) are reported, } \\
\text { for indirect interactions, see Table } 2 \text {. Here, ncRNAs in the same Table row do not necessarily interact with each } \\
\text { other, forming ceRNA couples, for this information and for the bibliographic references supporting these data, } \\
\text { we redirect the reader to Table } 1 \text {. For simplicity, genes for which no known interacting ncRNA is identified to } \\
\text { date are collectively listed in the last row of the table; n/a, data not available. }\end{array}$} \\
\hline
\end{tabular}

The above lists are likely to be further expanded in the next few years, which will likely provide a more comprehensive picture of EC etiology. However, available data are already enough to draw some conclusions. Firstly, the target proteins altered in EC (Column 5 in Table 1, and Columns 4 and 5 in Table 2) usually do not carry mutations in their coding sequence. This means that the direct sequencing of the DNA of these genes might bring to inaccurate molecular diagnosis because of the lack of DNA alterations. Such conclusion is equally true for the genes identified by the classification schemes used to date and described in Section 2 (Table 3). Indeed, the deregulation caused by ncRNA occurs mainly at the post-transcriptional level, leaving the DNA untouched. As a consequence, also the molecular diversity of EC in different patients is highly underestimated, potentially bearing to inefficient treatments. This brings to the second conclusion, most ncRNA characterized to date affect only a limited number of cell functions (Column 3 in Tables 1 and 2) that are nonetheless central in cell replication and survival. This is, at the same time, both a strength and a weakness of these studies. A strength, because having only specific functions altered, it allows to potentially select specific therapeutic targets. For example, in many instances, some proteins are involved more frequently than expected, such as PTEN, mTOR, AKT, MMPs, PI3K, MAPK, Notch, cadherins, and vimentin. These are proteins that are often altered in many cancers, suggesting that efficient ways to impair their function in other tumor types might hint to a good strategy for treating EC as well. The weakness is represented by the fact that, at least in some of them, and especially for $\mathrm{miR}$, there are multiple targets hit at the same time, either directly or indirectly, which amplify the effects of the deregulated ncRNA inside tumor cells. Thus, focusing on only one target protein may not be sufficient to treat EC efficiently, because some metabolic pathways are redundantly altered. Moreover, in this case, a comprehensive analysis of these molecules is the way to pursue towards personalized medicine, in which each patient is characterized by a specific set of molecular alterations, whose targets are well defined, and for whom drawing a therapeutic strategy would yield better results. 


\section{2. ceRNA: At the Crossroad between Small and Long ncRNA Function in EC}

Competing endogenous RNAs (ceRNA) are a relatively recent classification of ncRNA based on functional assays. In the last years it has been repeatedly shown that, beyond acting on protein coding genes, ncRNA may also interact between each other (Figure 1D). The interaction occurs thanks to sequence homology, in a way that a given lncRNA may act as a sponge to inhibit the binding of one or more miR to its/their mRNA target. Here, we will refer to two interacting ncRNA as "ceRNA couples". This kind of interaction, and its deregulation, is present in several human diseases, including cardiovascular anomalies, neurodegenerative disorders, and various types of cancer [221,222].

The outcome of this competition depends on the intracellular amount of each ncRNA involved, recalling that every lncRNA may sponge different sncRNA at the same time. In case the lncRNA depletes the intracellular content of the inhibiting miR (see also Figure 1A), the target mRNA may be regularly translated, producing its protein and affecting cell growth depending on target gene function. This mechanism may be finely tuned, on the basis of the relative amounts of the three RNA (mRNA, IncRNA, and sncRNA) involved. In recent years, several examples of such an interaction have been recorded in EC as well. Table 1 shows the ceRNA couples so far identified, highlighted by the presence of one or more miR in Column 4. It is worth noting that in these cases, because of their peculiar function, lncRNA and sncRNA always have opposite signs in their expression, i.e., if the IncRNA is up-regulated (over-expressed), the corresponding $\mathrm{miR}$ is down-regulated because more lncRNA molecules are available to sponge miR and free up the target mRNA. Consequently, if the target mRNA encodes an oncogene, the up-regulation of the lncRNA makes it an oncogene as well (lncRNA and mRNA have the same sign, both increase or decrease at the same time), while the corresponding, "sponged" miR is functionally an oncosuppressor (inverse sign). Similar but opposite behavior for the other way around. It is important to keep this in mind, when planning for possible therapies in EC patients. This makes the molecular characterization of EC patients even trickier, not just because of the expression sign, the physician should consider, during therapy planning, not only the ncRNA that are deregulated, but also those molecules that interact with them either directly (Tables 1 and 2, Column 4, Table 3) or indirectly (Tables 1 and 2, Column 5). In fact, it is evident that the oncogenic or oncosuppressive role of the ncRNA is defined by its target(s), and not merely by its status (up- or down-regulated). Without this global vision of the problem, the risk of therapeutic failure is still considerable. In this perspective, it is clear that the old, dualistic classification of EC as types I and II [7] is no longer tenable, and even the one based on coding gene mutations is substantially lacking for the purpose of personalized medicine. Nonetheless, once understood, this complicated scenario may become a powerful weapon in the hands of skilled therapists, because the resulting therapy will consider not only the metabolic pathway of the identified ncRNA, but also possible redundancies or alternative pathways equally hit.

\subsection{Structural DNA Modifications in EC}

As stated before, epigenetic changes may also affect DNA structure. In this case, we are talking about local changes in the three-dimensional shape of DNA, which alters its binding affinity for transcription factors (TF). This change in TF behavior may increase or decrease target gene(s) expression, depending on the type of modification, functionally akin to a gene mutation. This chromatin remodeling is inheritable, although the DNA sequence of the target gene remains the same. From a chemical point of view, there are two main ways to change the DNA affinity for TF: DNA methylation and post-translational histone modifications.

The chemical modifications occurring directly on DNA mainly involve the methylation of Cytosine and, to a lesser extent, of Adenine. In particular, the most common modification is 5-methyl-cytosine (5-mC, cytosine methylated in C-5 carbon). DNA methyltransferases (DNMTs), which use S-adenosyl methionine (SAM) as the methyl donor, are the proteins involved in this process [223]. These modifications are reversible, thanks to the action of 
specific enzymes called demethylases. Of course, this process is highly regulated and occurs in the presence of specific consensus sequences, and only if specific biochemical signals are present inside the cell. The main targets of DNMTs are the so-called "CpG islands", (CpG being the abbreviation for $5^{\prime}-\mathrm{C}-\mathrm{p}$ (hosphate)-G-3', i.e., cytosine and guanine separated by only one phosphate group). CpGs are sequences enriched in Cytosine and Guanine, placed at the $5^{\prime}$-end of genes, involved in the transcriptional control of the downstream gene [224]. Once DNA modification is applied, specific DNMTs act to maintain the DNA methylation in place throughout cell cycles, hence the heritability of these changes. Notably, CpG distribution in human genome is not random [225], and alterations in DNMTs function has been associated with several types of cancer [226], including EC [29]. Global genome methylation in normal vs. neoplastic endometrium is different, and the amount of DNA methylation inside the same CpG island may also vary according to cell type, stage, or time (menstrual cycle) [227], indeed, at least four different subtypes of methylation clusters can be recognized in EC [8]. Remarkably, the data shown here have two important points of contact with what has been described in EC previously [29]. Firstly, many of the already described genes affected by altered methylation (PI3K, Wnt, p16, FGF, NRAS, ERK, PARP, etc.) are also direct or indirect targets of ncRNA action, this means that these genes may be responsible of EC development not only because of gene mutation or DNA methylation, but also as a consequence of altered control pathways driven by these RNA. This is in good agreement with what we stated before about the redundancy of genetic function impaired in EC. In other words, the same gene can be hit in different ways to cause neoplastic transformation: mutation of its coding sequence, transcriptional silencing, or post-transcriptional silencing. Thus, understanding "why" a certain gene function is modified in EC has a deep influence on the therapy selection, for example, using a drug inhibiting mTOR may be inefficient if mTOR is mutated (no protein/drug binding), but efficient if a wild type mTOR is overexpressed. Second, in a few cases (miR-143, miR-145, miR-148b, and miR-152, Table 2) DNMTs are directly influenced in their expression by ncRNA, indicating that these small molecules might potentially deregulate tens of genes by altering the methylation profile of endometrium cells. Then, it would be interesting to analyze if these miR targeting DNMTs also have an indirect effect on genes not listed in their indirect targets, such as PTEN (one of the most frequently altered genes in EC hit 15 times in Tables 1 and 2) or AKT (21 hits) or PI3K (12 hits). Similarly, it would be interesting to analyze those genes which are known to be deregulated in EC upon DNA methylation variation, but which are not (yet?) present in our target list in Tables 1 and 2, such as MLH1 and MGMT (hypermethylated) or BORIS and PAX2 (hypomethylated) [29]. This represents an additional layer of complexity in EC diagnosis and characterization, which needs to be taken into account in the perspective of personalized medicine.

Post-translational modification of histones is equally efficient in changing TF affinity for target DNA sequences. Histones are highly conserved proteins that represent the initial and lower organization of chromatin. There are four core histones, namely H2A, $\mathrm{H} 2 \mathrm{~B}, \mathrm{H} 3$, and H4, which assemble in two identical tetramers that make up an octamer around which DNA winds. Chemically, the interaction with DNA, charged negatively due to phosphate groups (acid), occurs because these proteins are positively charged (basic). The number of negative groups on DNA is fixed, but the number of charges on histones may be modified, by adding or deleting additional groups to their amino acids, especially at their $\mathrm{N}$-terminal tail. The modifications include acetylation, methylation, phosphorylation, ubiquitylation, sumoylation, ADP ribosylation, deimination, proline isomerization, crotonylation, propionylation, butyrylation, formylation, hydroxylation, and O-GlcNAcylation $[228,229]$. The complex changes - which may be present in several combinations and number, allowing scientists to define a "histone code" for chromatin structure-are capable of fine-tuning the gene expression in higher eukaryotes. These modifications change the affinity of histones with DNA, allowing to modify the tightness of the chromatin packing, and in turn the accessibility of TF to the promoter regions of the genes. This, of course, in addition to the "normally" occurring mutations in histone genes, 
which may be oncogenic as well [230]. The most active and best characterized histone modification proteins are histone acetyltransferases (HATs, which add acetyl groups to amino acids, mainly lysine), histone deacetylases (HDACs, which remove acetylation), histone methyltransferases (HMTs, which add methyl groups to amino acids, mainly lysine and arginine) and histone demethylases (HDMs, which remove methylation). Interestingly, these modifications resemble the behavior of those occurring on DNA, in that they vary in endometrium according to cell type, stage, and time [30]. The role of these proteins in EC has been at least partially expounded upon in several papers (see Reference [230] and references therein). As a general rule, acetylation opens up the chromatin structure, promoting gene transcription, while methylation action depends on the number and position of the modification, thus can either promote or repress gene function. HATs are frequently overexpressed in cancer tissues including EC, while HDACs act in the opposite way. Instead, the oncogenic action of HMTs and HDMs depends on the role they exert in a specific context [214]. The most studied in EC is EZH2, which methylates H3K27 residue. This protein is under the control of both lncRNA (NEAT1, which is a ceRNA on EZH2 mRNA with miR-144-3p and miR-146b-5p, and PCAT1) and sncRNA (miR-101, miR-101-3p, miR-137, and miR-26a). In addition, four other proteins involved in these processes can be found: $\mathrm{CHD7}$, involved in histone acetylation, under the control of the ceRNA couple LINC01410/miR-23; LSD1/KDM1A, a demethylase under the control of miR-137 (together with EZH2); KDM5B/JARID1B, another demethylase, under the control of miR-29c-3p; and HDAC6, a deacetylase, under the control of miR-206. It is apparent that these processes are also under the control of several and redundant ncRNA, indicating that for these processes a set of conclusions similar to those for DNA methylation can be drawn.

\section{Discussion}

The cornerstone of the oncological treatment improvement is to avoid therapeutic side effects while maintaining a safety radicality, to ensure the best possible prognosis for cancer patients.

The actual risk stratification of EC patients is mainly based on clinical-pathologic factors [5], emerging studies are suggesting the inclusion of additional genetic features to better define the prognosis of patients affected by EC, but they are not yet used in the present clinical decision-making process $[8,10]$.

Adjuvant treatments and patients' surveillance after surgical staging for EC is currently based on stage, clinical variables, and histological variables [5].

Genetic prognostic features are currently the subject of experimental studies that will guide the use of more or less aggressive treatments [10].

Currently, well-defined prognostic elements for a favorable prognosis are considered stage I, endometrioid histologic subtype, no LVSI, G1, POLE mutations, and CTNNB1 mutations $[5,8,10]$.

Prognostic elements for an unfavorable prognosis are considered to be advanced stage, non-endometrioid histologic subtype, LVSI, G3, copy number high, p53 mutations, and L1CAM overexpression $[5,8,10]$.

EC is a very heterogeneous disease characterized by different histotypes and multiple genetic alterations. The molecular diversity of EC in different patients is underestimated, potentially leading to the risk of under or overtreatment. For this reason, the results are sometimes confusing, with some patients classified as low-risk having an unfavorable course of the disease, while some others with high risk factors showing a long progressionfree survival.

Our analysis supports this vision: A growing list of hundreds of ncRNAs exists, all of them are deregulated in EC and may be extremely helpful in characterizing EC subtypes. Moreover, for a number of them, also a functional characterization is available, albeit sometimes partial, suggesting that the molecular complexity of EC is still far from being fully clarified. The recent evidence of this complexity, exponentially increasing in the last years, shows that a mere list of deregulated molecules is not sufficient for physicians, 
they need to rely on a full vision of the cross-interactions between the genome and the epigenome as well, in order to select the most effective therapeutic strategy. As such, the more information can be obtained by patients' specimen, the better. The development of diagnostic tools capable of analyzing hundreds of ncRNAs at the same time from small biopsy samples is not only technically feasible, but also desirable.

Recently, ncRNAs have been studied with high throughput sequencing aimed at identifying their expression profiles in EC patients and to define their function in EC progression [12].

Several studies have pointed to a connection between ncRNAs and EC prognosis $[12,31,63,74,78,98,104,134,163,166,219,231-235]$, however, such findings derive from dishomogeneous population samples.

Among the authors that show a correlation between ncRNAs and survival rates, Zhou and collaborators reported the prognostic value of a promising predictive model based on the expression of 11 lncRNAs associated with EC patients' survival data [231].

Ahsen and coworkers have shown a correlation between miRNA and lymph node metastasis [236].

Identifying prognostic biomarkers would be essential to reduce EC recurrence and mortality rates. To that end, we have herein proposed to create a specific panel, to be used with highly parallel genome sequencing, for searching protein coding genes mutations, and possibly regulators of the otherwise wild type genes as well. In this panel we may imagine to put a set of genes with a recognized function in EC, plus the ncRNAs known to control those genes (Tables 1-3), plus those markers whose function is not yet known, but that show high diagnostic value. The substantial complexity of the information obtainable from such an analysis will most likely allow for a far deeper diversification of patients' molecular profile, and aid for a more specific, personalized approach in EC treatment. We summarize these classes of molecules in Table 4.

Table 4. Proposal for a diagnostic panel for highly parallel sequencing approach.

\begin{tabular}{|c|c|c|c|c|}
\hline Target & Purpose & $\begin{array}{c}\text { Expected Analysis } \\
\text { Output }\end{array}$ & Candidate Genes & References \\
\hline Coding gene & Finding gene mutations & Sequence mutation(s) & $\begin{array}{c}\text { PTEN, VEGF, TP53, FGF, } \\
\text { PIK3CA, Ki-67, } \\
\beta \text {-Catenin, EGFR, } \\
\text { RAS-RAF-MEK-ERK } \\
\text { pathway, p21, p16, ERBB2, } \\
\text { E-Cadherin, ER, PR, Cox-2 }\end{array}$ & [237] \\
\hline
\end{tabular}

\begin{tabular}{|c|c|c|c|c|}
\hline lncRNA (a) & $\begin{array}{c}\text { EC marker and } \\
\text { identification of potential } \\
\text { target genes }\end{array}$ & Up-/down-regulation & See Table 1 (62 lncRNA) & See Table 1 \\
\hline sncRNA (a) & $\begin{array}{c}\text { EC marker and } \\
\text { identification of potential } \\
\text { target genes }\end{array}$ & Up-/down-regulation & $\begin{array}{l}\text { See Tables } 1 \text { and } 2 \\
\text { (127 miR) }\end{array}$ & See Table 2 \\
\hline lncRNA (b) & EC marker & Up-/down-regulation & $\begin{array}{l}\text { ENSG00000260684, } \\
\text { ENSG00000229589, } \\
\text { ENSG00000224037, } \\
\text { ENSG00000235499, } \\
\text { ENSG00000224905, } \\
\text { ENSG00000260992, } \\
\text { ENSG00000248008, } \\
\text { ENSG00000234945, } \\
\text { ENSG00000182648, } \\
\text { ENSG00000253636, } \\
\text { ENSG00000233760 }\end{array}$ & [231] \\
\hline sncRNA (b) & EC marker & Up-/down-regulation & Several tens & {$[12,26,27,31,236,237]$} \\
\hline
\end{tabular}

Note: Modern technologies allow us to put all of these molecules inside one or two chips and to have a complete analysis of EC samples in a few hours, with the advantage of a much better molecular characterization of the patient. Notes: (a) ncRNA with known function (see Tables 1 and 2), (b) ncRNA with unknown function but high diagnostic value. 
In addition, we believe that it would be also very interesting to investigate additional potential ncRNA markers that, to date, have not been explored in this cancer, such as YRNA, which might highlight additional actors in EC etiology and would suggest novel potential therapeutic targets [238]. The genetic and epigenetic characterization of patients could lead to surgical strategies (lymphadenectomy versus sentinel lymph node sampling versus total hysterectomy and bilateral salpingo-ophorectomy), adjuvant therapies (BRT versus EBRT versus chemotherapy), and patients' surveillance (strict follow up versus watchful waiting strategy).

\section{Conclusions}

Overall, ncRNAs seem to show an independent prognostic value, as compared with the well-known clinical variables. With further prospective studies, the ncRNAs could represent valuable biomarkers to improve risk stratification for EC patients.

A prospective and comprehensive analysis of ncRNAs is the way to move towards a personalized medicine, in which each patient is characterized by a specific set of molecular alterations, whose target are well defined, and for whom drawing a therapeutic strategy would likely lead to better results.

Author Contributions: Conceptualization: R.P., F.P., S.Z.; methodology: R.P., F.P., A.F.C.; data curation for EC genetics and treatment: F.P., A.F.C., F.S., C.G.; data curation for ncRNA: R.P., S.Z., G.S., A.M., E.M.; original draft preparation: R.P., S.Z. and F.P.; supervision: G.S., S.Z. All authors have read and agreed to the published version of the manuscript.

Funding: This research received no external funding.

Institutional Review Board Statement: Not applicable.

Informed Consent Statement: Not applicable.

Data Availability Statement: Not applicable.

Conflicts of Interest: Authors declare no conflict of interest.

\section{References}

1. Cancer Stat Facts: Uterine Cancer. Available online: https://seer.cancer.gov/statfacts/html/corp.html (accessed on 10 January 2021).

2. Ferlay, J.; Colombet, M.; Soerjomataram, I.; Dyba, T.; Randi, G.; Bettio, M.; Gavin, A.; Visser, O.; Bray, F. Cancer Incidence and Mortality Patterns in Europe: Estimates for 40 Countries and 25 Major Cancers in 2018. Eur. J. Cancer 2018, 103, 356-387. [CrossRef] [PubMed]

3. Braun, M.M.; Overbeek-Wager, E.A.; Grumbo, R.J. Diagnosis and Management of Endometrial Cancer. Am. Fam. Phys. 2016, 93, 468-474.

4. Lu, K.H.; Schorge, J.O.; Rodabaugh, K.J.; Daniels, M.S.; Sun, C.C.; Soliman, P.T.; White, K.G.; Luthra, R.; Gershenson, D.M.; Broaddus, R.R. Prospective Determination of Prevalence of Lynch Syndrome in Young Women with Endometrial Cancer. J. Clin. Oncol. 2007, 25, 5158-5164. [CrossRef] [PubMed]

5. Colombo, N.; Creutzberg, C.; Amant, F.; Bosse, T.; González-Martín, A.; Ledermann, J.; Marth, C.; Nout, R.; Querleu, D.; Mirza, M.; et al. ESMO-ESGO-ESTRO Consensus Conference on Endometrial Cancer: Diagnosis, Treatment and Follow-up. Ann. Oncol. 2016, 27, 16-41. [CrossRef]

6. Fung-Kee-Fung, M.; Dodge, J.; Elit, L.; Lukka, H.; Chambers, A.; Oliver, T. Follow-up after Primary Therapy for Endometrial Cancer: A Systematic Review. Gynecol. Oncol. 2006, 101, 520-529. [CrossRef]

7. Bokhman, J.V. Two Pathogenetic Types of Endometrial Carcinoma. Gynecol. Oncol. 1983, 15, 10-17. [CrossRef]

8. Cancer Genome Atlas Research Network; Kandoth, C.; Schultz, N.; Cherniack, A.D.; Akbani, R.; Liu, Y.; Shen, H.; Robertson, A.G.; Pashtan, I.; Shen, R.; et al. Integrated Genomic Characterization of Endometrial Carcinoma. Nature 2013, 497, 67-73. [CrossRef]

9. Stelloo, E.; Nout, R.A.; Osse, E.M.; Juergenliemk-Schulz, I.J.; Jobsen, J.J.; Lutgens, L.C.; Van Der Steen-Banasik, E.M.; Nijman, H.W.; Putter, H.; Bosse, T.; et al. Improved Risk Assessment by Integrating Molecular and Clinicopathological Factors in Early-stage Endometrial Cancer-Combined Analysis of the PORTEC Cohorts. Clin. Cancer Res. 2016, 22, 4215-4224. [CrossRef]

10. PORTEC-4a, Version 2.5.1, 26 June 2020. NCT03469674. Available online: https:/ clinicaltrials.gov/ct2/show / NCT03469674 (accessed on 10 January 2021).

11. Vallone, C.; Rigon, G.; Gulia, C.; Baffa, A.; Votino, R.; Morosetti, G.; Zaami, S.; Briganti, V.; Catania, F.; Gaffi, M.; et al. Non-Coding RNAs and Endometrial Cancer. Genes 2018, 9, 187. [CrossRef] 
12. Zhao, D.; Ren, C.; Yao, Y.; Wang, Q.; Li, F.; Li, Y.; Jiang, A.; Wang, G. Identifying Prognostic Biomarkers in Endometrial Carcinoma Based on Cerna Network. J. Cell. Biochem. 2019, 121, 2437-2446. [CrossRef]

13. Ritterhouse, L.L.; Howitt, B.E. Molecular Pathology. Surg. Pathol. Clin. 2016, 9, 405-426. [CrossRef]

14. HGNC. HUGO Gene Nomenclature Committee. Available online: https://www.genenames.org/data/gene-symbol-report/\#! /hgnc_id/HGNC:9177 (accessed on 10 January 2021).

15. Yu, S.; Shao, H.; Ban, X.; Zhang, H.; You, Y.; Zhou, N.; Mao, X.; Zhao, H.; Chen, J.; Lu, Z. Detection of POLE Subtypes in High-Grade Endometrioid Carcinoma by BaseScope-ISH Assay. Front. Oncol. 2019, 9, 831. [CrossRef]

16. Oldfield, L.E.; Li, T.; Tone, A.; Aronson, M.; Edwards, M.; Holter, S.; Quevedo, R.; Van De Laar, E.; Lerner-Ellis, J.; Pollett, A.; et al. An Integrative DNA Sequencing and Methylation Panel to Assess Mismatch Repair Deficiency. J. Mol. Diagn. 2021, $23,242-252$. [CrossRef]

17. Klaus, A.; Birchmeier, W. Wnt Signalling and Its Impact on Development and Cancer. Nat. Rev. Cancer 2008, 8, 387-398. [CrossRef]

18. Levine, A.J. p53: 800 Million Years of Evolution and 40 Years of Discovery. Nat. Rev. Cancer 2020, 20, 471-480. [CrossRef]

19. Rathjen, F.; Schachner, M. Immunocytological and Biochemical Characterization of a New Neuronal Cell Surface Component (L1 Antigen) Which Is Involved in Cell Adhesion. EMBO J. 1984, 3, 1-10. [CrossRef]

20. Zeimet, A.G.; Reimer, D.; Huszar, M.; Winterhoff, B.; Puistola, U.; Azim, S.A.; Müller-Holzner, E.; Ben-Arie, A.; Van Kempen, L.C.; Petru, E.; et al. L1CAM in Early-Stage Type I Endometrial Cancer: Results of a Large Multicenter Evaluation. J. Natl. Cancer Inst. 2013, 105, 1142-1150. [CrossRef]

21. Ponting, C.P.; Hardison, R.C. What Fraction of the Human Genome Is Functional? Genome Res. 2011, 21, 1769-1776. [CrossRef]

22. Ling, H.; Vincent, K.; Pichler, M.; Fodde, R.; Berindan-Neagoe, I.; Slack, F.; Calin, G. Junk DNA and the Long Non-Coding RNA Twist in Cancer Genetics. Oncogene 2015, 34, 5003-5011. [CrossRef]

23. Handy, D.E.; Castro, R.; Loscalzo, J. Epigenetic Modifications. Circulation 2011, 123, 2145-2156. [CrossRef]

24. Nebbioso, A.; Tambaro, F.P.; Dell'Aversana, C.; Altucci, L. Cancer Epigenetics: Moving Forward. PLoS Genet. 2018, 14, e1007362. [CrossRef]

25. Kanwal, R.; Gupta, K.; Gupta, S. Cancer Epigenetics: An Introduction. Methods Mol. Biol. 2014, 3-25. [CrossRef]

26. Jurcevic, S.; Olsson, B.; Klinga-Levan, K. MicroRNA Expression in Human Endometrial Adenocarcinoma. Cancer Cell Int. 2014, 14, 1-8. [CrossRef] [PubMed]

27. Ouyang, D.; Li, R.; Li, Y.; Zhu, X. Construction of a Competitive Endogenous RNA Network in Uterine Corpus Endometrial Carcinoma. Med. Sci. Monit. 2019, 25, 7998-8010. [CrossRef] [PubMed]

28. Razavi, Z.S.; Tajiknia, V.; Majidi, S.; Ghandali, M.; Mirzaei, H.R.; Rahimian, N.; Hamblin, M.R.; Mirzaei, H. Gynecologic Cancers and Non-coding RNAs: Epigenetic Regulators with Emerging Roles. Crit. Rev. Oncol. 2021, 157, 103192. [CrossRef] [PubMed]

29. Bartosch, C.; Lopes, J.M.; Jerónimo, C. Epigenetics in Endometrial Carcinogenesis—Part 1: DNA Methylation. Epigenomics 2017, 9, 737-755. [CrossRef]

30. Bartosch, C.; Lopes, J.M.; Jerónimo, C. Epigenetics in Endometrial Carcinogenesis-Part 2: Histone Modifications, Chromatin Remodeling and Noncoding RNAs. Epigenomics 2017, 9, 873-892. [CrossRef]

31. Xia, L.; Wang, Y.; Meng, Q.; Su, X.; Shen, J.; Wang, J.; He, H.; Wen, B.; Zhang, C.; Xu, M. Integrated Bioinformatic Analysis of a Competing Endogenous RNA Network Reveals a Prognostic Signature in Endometrial Cancer. Front. Oncol. 2019,9 , 448. [CrossRef]

32. Gulìa, C.; Baldassarra, S.; Signore, F.; Rigon, G.; Pizzuti, V.; Gaffi, M.; Briganti, V.; Porrello, A.; Piergentili, R. Role of Non-Coding RNAs in the Etiology of Bladder Cancer. Genes 2017, 8, 339. [CrossRef]

33. Liu, Y.; Wang, L.-L.; Chen, S.; Zong, Z.-H.; Guan, X.; Zhao, Y. LncRNA ABHD11-AS1 Promotes the Development of Endometrial Carcinoma by Targeting Cyclin D1. J. Cell. Mol. Med. 2018, 22, 3955-3964. [CrossRef]

34. Gu, Z.-R.; Liu, Q. The LncRNA AL161431.1 Targets miR-1252-5p and Facilitates Cellular Proliferation and Migration via MAPK Signaling in Endometrial Carcinoma. Eur. Rev. Med. Pharmacol. Sci. 2020, 24, 2294-2302.

35. Zhai, W.; Li, X.; Wu, S.; Zhang, Y.; Pang, H.; Chen, W. Microarray Expression Profile of lncRNAs and the Upregulated ASLNC04080 lncRNA in Human Endometrial Carcinoma. Int. J. Oncol. 2015, 46, 2125-2137. [CrossRef]

36. Wang, D.; Wang, D.; Wang, N.; Long, Z.; Ren, X. Long Non-Coding RNA BANCR Promotes Endometrial Cancer Cell Proliferation and Invasion by Regulating MMP2 and MMP1 via ERK/MAPK Signaling Pathway. Cell. Physiol. Biochem. 2016, 40, 644-656. [CrossRef]

37. Liu, J.; Nie, S.; Liang, J.; Jiang, Y.; Wan, Y.; Zhou, S.; Cheng, W. Competing Endogenous RNA Network of Endometrial Carcinoma: A Comprehensive Analysis. J. Cell. Biochem. 2019, 120, 15648-15660. [CrossRef]

38. Zhao, X.; Wei, X.; Zhao, L.; Shi, L.; Cheng, J.; Kang, S.; Zhang, H.; Zhang, J.; Li, L.; Zhang, H.; et al. The rs6983267 SNP and Long Non-coding RNACARLo-5are Associated with Endometrial Carcinoma. Environ. Mol. Mutagen. 2016, 57, 508-515. [CrossRef]

39. Yu, J.; Jiang, L.; Gao, Y.; Sun, Q.; Liu, B.; Hu, Y.; Han, X. LncRNA CCAT1 Negatively Regulates miR 181a 5p to Promote Endometrial Carcinoma Cell Proliferation and Migration. Exp. Ther. Med. 2019, 17, 4259-4266. [CrossRef]

40. Treeck, O.; Skrzypczak, M.; Schüler-Toprak, S.; Weber, F.; Ortmann, O. Long Non-coding RNA CCAT1 Is Overexpressed in Endometrial Cancer and Regulates Growth and Transcriptome of Endometrial Adenocarcinoma Cells. Int. J. Biochem. Cell Biol. 2020, 122, 105740. [CrossRef]

41. Xie, P.; Cao, H.; Li, Y.; Wang, J.; Cui, Z. Knockdown of lncRNA CCAT2 Inhibits Endometrial Cancer Cells Growth and Metastasis via Sponging miR-216b. Cancer Biomarkers 2017, 21, 123-133. [CrossRef] 
42. Shang, C.; Ao, C.N.; Cheong, C.C.; Meng, L. Long Non-coding RNA CDKN2B Antisense RNA 1 Gene Contributes to Paclitaxel Resistance in Endometrial Carcinoma. Front. Oncol. 2019, 9, 27. [CrossRef]

43. Shi, Y.; Zha, J.; Zuo, M.; Yan, Q.; Song, H. Long Noncoding RNA CHL1-AS1 Promotes Cell Proliferation and Migration by Sponging miR-6076 to Regulate CHL1 Expression in Endometrial Cancer. J. Cell. Biochem. 2019, 121, 2655-2663. [CrossRef]

44. Shen, Q.; He, T.; Yuan, H. Hsa_circ_0002577 Promotes Endometrial Carcinoma Progression via Regulating miR-197/CTNND1 Axis and Activating Wnt/ $\beta$-Catenin Pathway. Cell Cycle 2019, 18, 1229-1240. [CrossRef] [PubMed]

45. Xu, H.; Gong, Z.; Shen, Y.; Fang, Y.; Zhong, S. Circular RNA Expression in Extracellular Vesicles Isolated from Serum of Patients with Endometrial Cancer. Epigenomics 2018, 10, 187-197. [CrossRef]

46. Liu, Y.; Chang, Y.; Cai, Y. Hsa_circ_0061140 Promotes Endometrial Carcinoma Progression via Regulating miR-149-5p/STAT3. Gene 2020, 745, 144625. [CrossRef] [PubMed]

47. Sun, J.; Gao, S.; Lu, C. Knockdown of Differentiation Antagonizing Non-protein Coding RNA Exerts Anti-tumor Effect by up-Regulating miR-214 in Endometrial Carcinoma. Mol. Cell. Biochem. 2019, 460, 9-15. [CrossRef] [PubMed]

48. Ke, J.; Shen, Z.; Hu, W.; Li, M.; Shi, Y.; Xie, Z.; Wu, D. LncRNA DCST1-AS1 Was Upregulated in Endometrial Carcinoma and May Sponge miR-92a-3p to Upregulate Notch1. Cancer Manag. Res. 2020, ume 12, 1221-1227. [CrossRef]

49. Shao, W.; Li, Y.; Chen, F.; Jia, H.; Jia, J.; Fu, Y. Long Non-Coding RNA DLEU1 Contributes to the Development of Endometrial Cancer by Sponging miR-490 to Regulate SP1 Expression. Die Pharm. 2018, 73, 379-385.

50. Du, Y.; Wang, L.; Chen, S.; Liu, Y.; Zhao, Y. lncRNA DLEU1 Contributes to Tumorigenesis and Development of Endometrial Carcinoma by Targeting mTOR. Mol. Carcinog. 2018, 57, 1191-1200. [CrossRef]

51. Kong, Y.; Ren, Z. Overexpression of LncRNA FER1L4 in Endometrial Carcinoma Is Associated with Favorable Survival Out-come. Eur. Rev. Med. Pharmacol. Sci. 2018, 22, 8113-8118. [CrossRef]

52. Qiao, Q.; Li, H. LncRNA FER1L4 Suppresses Cancer Cell Proliferation and Cycle by Regulating PTEN Expression in Endometrial Carcinoma. Biochem. Biophys. Res. Commun. 2016, 478, 507-512. [CrossRef]

53. Wang, J.; Li, Z.; Wang, X.; Ding, Y.; Li, N. The Tumor Suppressive Effect of Long Non-coding RNA FRMD6-AS2 in Uteri Corpus Endometrial Carcinoma. Life Sci. 2020, 243, 117254. [CrossRef]

54. Li, Z.; Yu, Z.; Meng, X.; Zhou, S.; Xiao, S.; Li, X.; Liu, S.; Yu, P. Long Noncoding RNA GAS5 Impairs the Proliferation and In-vasion of Endometrial Carcinoma Induced by High Glucose via Targeting MiR-222-3p/P27. Am. J. Transl. Res. 2019, 11, $2413-2421$.

55. Guo, C.; Song, W.-Q.; Sun, P.; Jin, L.; Dai, H.-Y. LncRNA-GAS5 Induces PTEN Expression through Inhibiting miR-103 in Endometrial Cancer Cells. J. BioMed. Sci. 2015, 22, 100. [CrossRef]

56. Tanos, V.; Ariel, I.; Prus, D.; De-Groot, N.; Hochberg, A. H19 and IGF2 Gene Expression in Human Normal, Hyperplastic, and Malignant Endometrium. Int. J. Gynecol. Cancer 2004, 14, 521-525. [CrossRef]

57. Lottin, S.; Adriaenssens, E.; Berteaux, N.; Lepretre, A.; Vilain, M.-O.; Denhez, E.; Coll, J.; Dugimont, T.; Curgy, J.-J. The Human H19 Gene Is Frequently Overexpressed in Myometrium and Stroma during Pathological Endometrial Proliferative Events. Eur. J. Cancer 2005, 41, 168-177. [CrossRef]

58. Zhao, L.; Li, Z.; Chen, W.; Zhai, W.; Pan, J.; Pang, H.; Li, X. H19 Promotes Endometrial Cancer Progression by Modulating Epithelial-Mesenchymal Transition. Oncol. Lett. 2017, 13, 363-369. [CrossRef]

59. Zhang, L.; Wang, D.-L.; Yu, P. LncRNA H19 Regulates the Expression of Its Target Gene HOXA10 in Endometrial Carcinoma through Competing With miR-612. Eur. Rev. Med. Pharmacol. Sci. 2018, 22, 4820-4827.

60. Zhu, H.; Jin, Y.-M.; Lyu, X.-M.; Fan, L.-M.; Wu, F. Long Noncoding RNA H19 Regulates HIF-1 $\alpha /$ AXL Signaling through Inhibiting miR-20b-5p in Endometrial Cancer. Cell Cycle 2019, 18, 2454-2464. [CrossRef]

61. Liu, S.; Qiu, J.; Tang, X.; Cui, H.; Zhang, Q.; Yang, Q. LncRNA-H19 Regulates Cell Proliferation and Invasion of Ectopic Endometrium by Targeting ITGB3 via Modulating miR-124-3p. Exp. Cell Res. 2019, 381, 215-222. [CrossRef]

62. Yang, X.; Wang, C.C.; Lee, W.Y.W.; Trovik, J.; Chung, T.K.H.; Kwong, J. Long Non-coding RNA HAND2-as1 Inhibits Invasion and Metastasis in Endometrioid Endometrial Carcinoma through Inac-Tivating Neuromedin U. Cancer Lett. 2018, 413, 23-34. [CrossRef]

63. He, X.; Bao, W.; Li, X.; Chen, Z.; Che, Q.; Wang, H.; Wan, X.-P. The Long Non-coding RNA HOTAIR Is Upregulated in Endometrial Carcinoma and Correlates with Poor Prognosis. Int. J. Mol. Med. 2013, 33, 325-332. [CrossRef]

64. Huang, J.; Ke, P.; Guo, L.; Wang, W.; Tan, H.; Liang, Y.; Yao, S. Lentivirus-Mediated RNA Interference Targeting the Long Noncoding RNA HOTAIR Inhibits Proliferation and Invasion of Endometrial Carcinoma Cells In Vitro and In Vivo. Int. J. Gynecol. Cancer 2014, 24, 635-642. [CrossRef] [PubMed]

65. Sun, M.-Y.; Zhu, J.-Y.; Zhang, C.-Y.; Zhang, M.; Song, Y.-N.; Rahman, K.; Zhang, L.-J.; Zhang, H. Autophagy Regulated by lncRNA HOTAIR Contributes to the Cisplatin-Induced Resistance in Endometrial Cancer Cells. Biotechnol. Lett. 2017, 39, 1477-1484. [CrossRef] [PubMed]

66. Zhou, Y.-X.; Wang, C.; Mao, L.-W.; Wang, Y.-L.; Xia, L.-Q.; Zhao, W.; Shen, J.; Chen, J. Long Noncoding RNA HOTAIR Mediates the Estrogen-Induced Metastasis of Endometrial Cancer Cells via the miR-646/NPM1 Axis. Am. J. Physiol. Physiol. 2018, 314, C690-C701. [CrossRef] [PubMed]

67. Chi, S.; Liu, Y.; Zhou, X.; Feng, D.; Xiao, X.; Li, W.; Zhao, Y.; Wang, H. Knockdown of Long Non-coding HOTAIR Enhances the Sensitivity to Progesterone in Endometrial Cancer by Epigenetic Regu-Lation of Progesterone Receptor Isoform B. Cancer Chemother. Pharmacol. 2019, 83, 277-287. [CrossRef] 
68. Zhang, X.-H.; Hu, P.; Xie, Y.-Q.; Kang, Y.-J.; Li, M. Long Noncoding RNA HOTAIR Promotes Endometrial Carcinoma Cell Proliferation by Binding to PTEN via the Activating Phosphatidylinositol 3-Kinase/Akt Signaling Pathway. Mol. Cell. Biol. 2019, 39, e00251-19. [CrossRef]

69. Li, X.; Pang, L.; Yang, Z.; Liu, J.; Li, W.; Wang, D. LncRNA HOTAIRM1/HOXA1 Axis Promotes Cell Proliferation, Migration and Invasion in Endometrial Cancer. OncoTargets Ther. 2019, ume 12, 10997-11015. [CrossRef]

70. Liu, D.; Qiu, M.; Jiang, L.; Liu, K. Long Noncoding RNA HOXB-AS1 Is Upregulated in Endometrial Carcinoma and Sponged miR-149-3p to Upregulate Wnt10b. Technol. Cancer Res. Treat. 2020, 19, 153303382096746. [CrossRef]

71. Xin, W.; Zhao, S.; Han, X.; Zhao, P.; Yu, H.; Gao, X.; Li, P.; Wu, Q.; Ding, J.; Hua, K. IncRNA LA16c-313D11.11 Modulates the Development of Endometrial Cancer by Binding to and Inhibiting microRNA 2055 punction and Indirectly in-Creasing PTEN activity. Int. J. Oncol. 2020, 57, 355-363. [CrossRef]

72. Fang, Q.; Sang, L.; Du, S. Long Noncoding RNA LINC00261 Regulates Endometrial Carcinoma Progression by Modulating miRNA/FOXO1 Expression. Cell Biochem. Funct. 2018, 36, 323-330. [CrossRef]

73. Li, W.; Li, H.; Zhang, L.; Hu, M.; Li, F.; Deng, J.; An, M.; Wu, S.; Ma, R.; Lu, J.; et al. Long non-coding RNA LINC00672 contributes to $\mathrm{p} 53$ protein-mediated gene suppression and promotes endometrial cancer chemosensitivity. J. Biol. Chem. 2017, 292, 5801-5813. [CrossRef]

74. Wang, Y.; Huang, T.; Sun, X.; Wang, Y. Identification of a Potential Prognostic lncRNA-miRNA-mRNA Signature in Endometrial Cancer Based on the Competing Endogenous RNA Network. J. Cell. Biochem. 2019, 120, 18845-18853. [CrossRef]

75. Pan, X.; Li, D.; Huo, J.; Kong, F.; Yang, H.; Ma, X. LINC01016 Promotes the Malignant Phenotype of Endometrial Cancer Cells by Regulating the miR-302a-3p/miR-3130-3p/NFYA/SATB1 axis. Cell Death Dis. 2018, 9, 303. [CrossRef]

76. Zhang, Z.; Liu, X.; Xu, H.; Li, P.; Zeng, T.; Du, W.; Lu, X. LINC01170 Promotes the Progression of Endometrial Carcinoma by Activating the Akt Pathway. J. BUON Off. J. Balk. Union Oncol. 2019, 23, 1745-1752.

77. Li, Y.; Kong, C.; Wu, C.; Wang, Y.; Xu, B.; Liang, S.; Ying, X.; Wu, C. Knocking Down of LINC01220 Inhibits Proliferation and Induces Apoptosis of Endometrial Carcinoma through Silencing MAPK11. Biosci. Rep. 2019, 39, 20181794. [CrossRef]

78. Lu, M.; Ding, N.; Zhuang, S.; Li, Y. LINC01410/miR-23c/CHD7 Functions as a ceRNA Network to Affect the Prognosis of Patients with Endometrial Cancer and Strengthen the Malignant Properties of Endometrial Cancer Cells. Mol. Cell. Biochem. 2020, 469, 9-19. [CrossRef]

79. Zhou, X.; Gao, Q.; Wang, J.; Zhang, X.; Liu, K.; Duan, Z. Linc-RNA-RoR Acts as a "Sponge" against Mediation of the Differentiation of Endometrial Cancer Stem Cells by microRNA-145. Gynecol. Oncol. 2014, 133, 333-339. [CrossRef]

80. Zhang, X.-H.; Li, M.; Kang, Y.-J.; Xie, Y.-Q.; Cao, Y.-X. Long Non-Coding RNA LINP1 Functions as an Oncogene in Endometrial Cancer Progression by Regulating the PI3K/AKT Signaling Pathway. Eur. Rev. Med. Pharmacol. Sci 2019, $23,6830-6838$.

81. Sun, L.; Zhou, R.; Dong, J.; Liu, S.; Jiao, Y.; Wang, L.; Hu, S.; He, P.; Liu, X.; Zhao, X.; et al. Lnc-NA Inhibits Proliferation and Metastasis in Endometrioid Endometrial Carcinoma through Regulation of NR4A1. J. Cell. Mol. Med. 2019, 23, 4699-4710. [CrossRef]

82. Liu, Y.; Chang, Y.; Cai, Y.-X. Inhibition of Lnc-OC1 Induced Cell Apoptosis and Decreased Cell Viability by Releasing miR-34a and Inhibiting PD-L1 in Endometrial Carcinoma. Reprod. Sci. 2020, 27, 1848-1856. [CrossRef]

83. Zheng, X.; Liu, M.; Song, Y.; Feng, C. Long Noncoding RNA-ATB Impairs the Function of Tumor Suppressor miR-126-Mediated Signals in Endometrial Cancer for Tumor Growth and Metastasis. Cancer Biother. Radiopharm. 2019, 34, 47-55. [CrossRef]

84. Guo, J.-L.; Tang, T.; Li, J.-H.; Yang, Y.-H.; Zhang, L.; Quan, Y. LncRNA HEIH Enhances Paclitaxel-Tolerance of Endometrial Cancer Cells via Activation of MAPK Signaling Pathway. Pathol. Oncol. Res. 2019, 26, 1757-1766. [CrossRef] [PubMed]

85. Li, F.; Li, H.; Zhang, L.; Li, W.; Deng, J.; An, M.; Wu, S.; Lu, X.; Ma, R.; Wang, Y.; et al. X Chromosome-Linked Long Noncoding RNA lnc-XLEC1 regulates c-Myc-Dependent Cell Growth by Collaborating with MBP-1 in Endometrial Cancer. Int. J. Cancer 2019, 145, 927-940. [CrossRef] [PubMed]

86. Xu, H.; Sun, Y.; Ma, Z.; Xu, X.; Qin, L.; Luo, B. LOC134466 Methylation Promotes Oncogenesis of Endometrial Carcinoma Through LOC134466/hsa-miR-196a-5p/TAC1 axis. Aging 2018, 10, 3353-3370. [CrossRef] [PubMed]

87. Yang, X.; Xing, G.; Liu, S.; Li, B.; He, Y.; Wang, F. LncRNA LOXL1-AS1 Promotes Endometrial Cancer Progression by Sponging miR-28-5p to Upregulate RAP1B Expression. BioMed. Pharmacother. 2020, 125, 109839. [CrossRef]

88. Li, Q.; Zhang, C.; Chen, R.; Xiong, H.; Qiu, F.; Liu, S.; Zhang, M.; Wang, F.; Wang, Y.; Zhou, X.; et al. Disrupting MALAT1/miR-200c Sponge Decreases Invasion and Migration in Endometrioid Endometrial Carcinoma. Cancer Lett. 2016, 383, 28-40. [CrossRef]

89. Guo, Q.; Qian, Z.; Yan, D.; Li, L.; Huang, L. LncRNA-MEG3 Inhibits Cell Proliferation of Endometrial Carcinoma by Repressing Notch Signaling. BioMed. Pharmacother. 2016, 82, 589-594. [CrossRef]

90. Sun, K.-X.; Wu, D.-D.; Chen, S.; Zhao, Y.; Zong, Z.-H. LncRNA MEG3 Inhibit Endometrial Carcinoma Tumorigenesis and Progression through PI3K Pathway. Apoptosis 2017, 22, 1543-1552. [CrossRef]

91. Shi, F.; Wang, T.; Liu, Z.; Zhang, Y.; Wang, J.; Zhang, K.; Su, J. LncRNA miR143HG Up-Regulates p53 In Endometrial Carcinoma by Sponging miR-125a. Cancer Manag. Res. 2019, ume 11, 10117-10123. [CrossRef]

92. Cui, Z.; An, X.; Li, J.; Liu, Q.; Liu, W. LncRNA MIR22HG Negatively Regulates miR-141-3p to Enhance DAPK1 Expression and Inhibits Endometrial Carcinoma Cells Proliferation. BioMed. Pharmacother. 2018, 104, 223-228. [CrossRef]

93. Wang, W.; Ge, L.; Xu, X.-J.; Yang, T.; Yuan, Y.; Ma, X.-L.; Zhang, X.-H. LncRNA NEAT1 Promotes Endometrial Cancer Cell Proliferation, Migration and Invasion by Regulating the miR-144-3p/EZH2 Axis. Radiol. Oncol. 2019, 53, 434-442. [CrossRef] 
94. Dong, P.; Xiong, Y.; Yue, J.; Xu, D.; Ihira, K.; Konno, Y.; Kobayashi, N.; Todo, Y.; Watari, H. Long Noncoding RNA NEAT1 Drives Aggressive Endometrial Cancer Progression via Mir-361-Regulated Networks Involving STAT3 and Tumor Microenvi-RonmentRelated Genes. J. Exp. Clin. Cancer Res. 2019, 38, 1-15. [CrossRef]

95. Huang, X.; Zhong, R.; He, X.; Deng, Q.; Peng, X.; Li, J.; Luo, X. Investigations on the Mechanism of Progesterone in Inhibiting Endometrial Cancer Cell Cycle and Viability via Regulation of Long Noncoding RNA NEAT1/microRNA-146b-5p Mediated Wnt/ $\beta$-catenin signaling. IUBMB Life 2019, 71, 223-234. [CrossRef]

96. Zhou, Y.-X.; Zhao, W.; Mao, L.-W.; Wang, Y.-L.; Xia, L.-Q.; Cao, M.; Shen, J.; Chen, J. Long Non-Coding RNA NIFK-AS1 Inhibits M2 Polarization of Macrophages in Endometrial Cancer through Targeting miR-146a. Int. J. Biochem. Cell Biol. 2018, 104, 25-33. [CrossRef]

97. Wang, L.; Zhao, S.; Mingxin, Y.U. LncRNA NR2F1-AS1 Is Involved in the Progression of Endometrial Cancer by Sponging miR-363 to target SOX4. Die Pharm. 2019, 74, 295-300.

98. Zhao, X.; Fan, Y.; Lu, C.; Li, H.; Zhou, N.; Sun, G.; Fan, H. PCAT1 Is a Poor Prognostic Factor in Endometrial Carcinoma and Associated with Cancer Cell Proliferation, Migration and Invasion. Bosn. J. Basic Med. Sci. 2019, 19, 274-281. [CrossRef]

99. Zhang, C.; Shao, S.; Zhang, Y.; Wang, L.; Liu, J.; Fang, F.; Li, P.; Wang, B. LncRNA PCAT1 Promotes Metastasis of Endometrial Carcinoma through Epigenetical Downregulation of E-cadherin Associated with Methyl-Transferase EZH2. Life Sci. 2020, 243, 117295. [CrossRef]

100. Li, Q.; Shen, F.; Zhao, L. The Relationship between lncRNA PCGEM1 and STAT3 During the Occurrence and Development of Endometrial Carcinoma. BioMed. Pharmacother. 2018, 107, 918-928. [CrossRef]

101. Kong, F.; Ma, J.; Yang, H.; Yang, D.; Wang, C.; Ma, X. Long Non-Coding RNA PVT1 Promotes Malignancy in Human Endometrial Carcinoma Cells through Negative Regulation of miR-195-5p. Biochim. Biophys. Acta (BBA) Bioenerg. 2018, 1865, 1479-1490. [CrossRef]

102. Xing, T.-R.; Chen, P.; Wu, J.-M.; Gao, L.-L.; Yang, W.; Cheng, Y.; Tong, L.-B. UPF1 Participates in the Progression of Endometrial Cancer by Inhibiting the Expression of IncRNA PVT1. OncoTargets Ther. 2020, ume 13, 2103-2114. [CrossRef]

103. Zhang, Y.; Zhang, P.; Chen, L.; Zhao, L.; Zhu, J.; Zhu, T. The Long Non-Coding RNA-14327.1 Promotes Migration and Invasion Potential of Endometrial Carcinoma Cells by Stabilizing the Potassium Channel Kca3.1. OncoTargets Ther. 2019, ume 12, 10287-10297. [CrossRef]

104. Gao, L.; Nie, X.; Zhang, W.; Gou, R.; Hu, Y.; Qi, Y.; Li, X.; Liu, Q.; Liu, J.; Lin, B. Identification of Long Noncoding RNA RP11-89K21.1 and RP11-357H14.17 as Prognostic Signature of Endometrial Carcinoma via Integrated Bioinformatics Analysis. Cancer Cell Int. 2020, 20, 1-18. [CrossRef]

105. Xin, W.; Gao, X.; Zhao, S.; Zhao, P.; Yu, H.; Wu, Q.; Hua, K. LncRNA RP11-395G23.3 Suppresses the Endometrial Cancer Progression via Regulating microRNA-205-5p/PTEN axis. Am. J. Transl. Res 2020, 12, 4422-4433.

106. Zhang, G.; Ma, A.; Jin, Y.; Pan, G.; Wang, C. LncRNA SNHG16 Induced by TFAP2A Modulates Glycolysis and Proliferation of Endometrial Carcinoma Through miR-490-3p/HK2 axis. Am. J. Transl. Res 2019, 11, 7137-7145.

107. Li, S.; Shan, Y.; Li, X.; Zhang, C.; Wei, S.; Dai, S.; Zhao, R.; Zhao, X.; Zhao, L.; Shan, B. IncRNA SNHG5 Modulates Endometrial Cancer Progression via the miR-25-3p/BTG2 Axis. J. Oncol. 2019, 2019, 1-12. [CrossRef]

108. Yang, C.-H.; Zhang, X.-Y.; Zhou, L.-N.; Wan, Y.; Song, L.-L.; Gu, W.-L.; Liu, R.; Ma, Y.-N.; Meng, H.-R.; Tian, Y.-L.; et al. LncRNA SNHG8 Participates in the Development of Endometrial Carcinoma through Regulating c-MET Expression by miR-152. Eur. Rev. Med. Pharmacol. Sci. 2018, 22, 1629-1637.

109. Park, S.-A.; Kim, L.K.; Kim, Y.T.; Heo, T.-H.; Kim, H.J. Long Non-coding RNA Steroid Receptor Activator Promotes the Progression of Endometrial Cancer via Wnt/ $\beta$-Catenin Signaling Pathway. Int. J. Biol. Sci. 2020, 16, 99-115. [CrossRef]

110. Chen, S.; Wang, L.-L.; Sun, K.-X.; Liu, Y.; Guan, X.; Zong, Z.-H.; Zhao, Y. LncRNA TDRG1 Enhances Tumorigenicity in Endometrial Carcinoma by Binding and Targeting VEGF-A protein. Biochim. Biophys. Acta (BBA) Mol. Basis Dis. 2018, 1864, $3013-3021$. [CrossRef] [PubMed]

111. Sun, R.; Sun, X.; Liu, H.; Li, P. Knockdown of lncRNA TDRG1 Inhibits Tumorigenesis in Endometrial Carcinoma Through the PI3K/AKT/mTOR Pathway. OncoTargets Ther. 2019, ume 12, 10863-10872. [CrossRef]

112. Liu, L.; Chen, X.; Zhang, Y.; Hu, Y.; Shen, X.; Zhu, W. Long Non-Coding RNA TUG1 Promotes Endometrial Cancer Development via Inhibiting miR-299 and miR-34a-5p. Oncotarget 2017, 8, 31386-31394. [CrossRef] [PubMed]

113. Shang, C.; Lang, B.; Ao, C.N.; Meng, L. Long Non-Coding RNA Tumor Suppressor Candidate 7 Advances Chemotherapy Sensitivity of Endometrial Carcinoma through Targeted Silencing of miR-23b. Tumor Biol. 2017, 39. [CrossRef] [PubMed]

114. Wu, X.; Cai, D.; Zhang, F.; Li, M.; Wan, Q. Long Noncoding RNA TUSC7 Inhibits Cell Proliferation, Migration and Invasion by Regulating SOCS4 (SOCS5) Expression through Targeting miR-616 in Endometrial Carcinoma. Life Sci. 2019, $231,116549$. [CrossRef]

115. Peng, J.-T.; Li, M.-C. A Functional Cis-EQTL Locus in LncRNA ZNRD1-AS1 Contributes to the Susceptibility of Endometrial Cancer. Eur. Rev. Med. Pharmacol. Sci. 2019, 23, 7802-7807. [CrossRef]

116. Konno, Y.; Dong, P.; Xiong, Y.; Suzuki, F.; Lu, J.; Cai, M.; Watari, H.; Mitamura, T.; Hosaka, M.; Hanley, S.J.B.; et al. MicroRNA-101 Targets EZH2, MCL-1 and FOS to Suppress Proliferation, Invasion and Stem Cell-like Phenotype of Aggressive Endometrial Cancer Cells. Oncotarget 2014, 5, 6049-6062. [CrossRef]

117. Zhang, S.; Wang, M.; Li, Q.; Zhu, P. MiR-101 Reduces Cell Proliferation and Invasion and Enhances Apoptosis in Endometrial Cancer via Regulating PI3K/Akt/mTOR. Cancer Biomark. 2021, 21, 179-186. [CrossRef] 
118. Liu, Y.; Li, H.; Zhao, C.; Jia, H. MicroRNA-101 Inhibits Angiogenesis via COX-2 in Endometrial Carcinoma. Mol. Cell. Biochem. 2018, 448, 61-69. [CrossRef]

119. Wang, C.; Liu, B. miR-101-3p Induces Autophagy in Endometrial Carcinoma Cells by Targeting EZH2. Arch. Gynecol. Obstet. 2018, 297, 1539-1548. [CrossRef]

120. Du, J.; Zhang, F.; Zhang, L.; Jia, Y.; Chen, H. MicroRNA-103 Regulates the Progression in Endometrial Carcinoma through ZO-1. Int. J. Immunopathol. Pharmacol. 2019, 33. [CrossRef]

121. Zhao, Z.-N.; Bai, J.-X.; Zhou, Q.; Yan, B.; Qin, W.-W.; Jia, L.-T.; Meng, Y.-L.; Jin, B.-Q.; Yao, L.-B.; Wang, T.; et al. TSA Suppresses miR-106b-93-25 Cluster Expression through Downregulation of MYC and Inhibits Proliferation and Induces Apoptosis in Human EMC. PLoS ONE 2012, 7, e45133. [CrossRef]

122. Tang, W.; Li, J.; Liu, H.; Zhou, F.; Liu, M. MiR-106a Promotes Tumor Growth, Migration, and Invasion by Targeting BCL2L11 in Human Endometrial Adenocarcinoma. Am. J. Transl. Res. 2017, 9, 4984-4993.

123. Zavesky, L.; Jandakova, E.; Turyna, R.; Langmeierova, L.; Weinberger, V.; Minar, L. Supernatant versus Exosomal Urinary MicroRNAs. Two Fractions with Different Outcomes in Gynaecological Cancers. Neoplasma 2016, 63, 121-132. [CrossRef]

124. Huang, C.; Hu, G. Shikonin Suppresses Proliferation and Induces Apoptosis in Endometrioid Endometrial Cancer Cells via Modulating miR-106b/PTEN/AKT/mTOR Signaling Pathway. Biosci. Rep. 2018, 38. [CrossRef] [PubMed]

125. Bao, W.; Zhang, Y.; Li, S.; Fan, Q.; Qiu, M.; Wang, Y.; Li, Y.; Ji, X.; Yang, Y.; Sang, Z.; et al. miR-107-5p Promotes Tumor Proliferation and Invasion by Targeting Estrogen Receptor $\alpha$ in Endometrial Carcinoma. Oncol. Rep. 2018, 41, 1575-1585. [CrossRef] [PubMed]

126. Chen, H.; Fan, Y.; Xu, W.; Chen, J.; Xu, C.; Wei, X.; Fang, D.; Feng, Y. miR-10b Inhibits Apoptosis and Promotes Proliferation and Invasion of Endometrial Cancer Cells via Targeting HOXB3. Cancer Biother. Radiopharm. 2016, 31, 225-231. [CrossRef]

127. Li, L.; Qu, Y.W.; Li, Y.P. Over-Expression of miR-1271 Inhibits Endometrial Cancer Cells Proliferation and Induces Cell B by Targeting CDK1. Eur. Rev. Med. Pharmacol. Sci. 2017, 21, 2816-2822. [PubMed]

128. Tian, Y.; Chen, Y.-Y.; Han, A.-L. MiR-1271 Inhibits Cell Proliferation and Metastasis by Targeting LDHA in Endometrial Cancer. Eur. Rev. Med. Pharmacol. Sci. 2019, 23, 5648-5656. [PubMed]

129. Dong, P.; Karaayvaz, M.; Jia, N.; Kaneuchi, M.; Hamada, J.; Watari, H.; Sudo, S.; Ju, J.; Sakuragi, N. Mutant p53 Gain-of-Function Induces Epithelial-Mesenchymal Transition through Modulation of the miR-130b-ZEB1 Axis. Oncogene 2012, 32, $3286-3295$. [CrossRef]

130. Gao, Y.; Liu, T.; Huang, Y. MicroRNA-134 Suppresses Endometrial Cancer Stem Cells by Targeting POGLUT1 and Notch Pathway Proteins. FEBS Lett. 2014, 589, 207-214. [CrossRef]

131. Zhang, W.; Chen, J.-H.; Shan, T.; Aguilera-Barrantes, I.; Wang, L.-S.; Huang, T.H.-M.; Rader, J.S.; Sheng, X.; Huang, Y.-W. miR-137 is a Tumor Suppressor in Endometrial Cancer and Is Repressed by DNA Hypermethylation. Lab. Investig. 2018, 98, 1397-1407. [CrossRef]

132. Liu, J.; Li, C.; Jiang, Y.; Wan, Y.; Zhou, S.; Cheng, W. Tumor-Suppressor Role of miR-139-5p in Endometrial Cancer. Cancer Cell Int. 2018, 18, 51. [CrossRef]

133. Su, Y.; Wang, J.; Ma, Z.; Gong, W.; Yu, L. miR-142 Suppresses Endometrial Cancer Proliferation In Vitro and In Vivo by Targeting Cyclin D1. DNA Cell Biol. 2019, 38, 144-150. [CrossRef]

134. Zhang, X.; Dong, Y.; Ti, H.; Zhao, J.; Wang, Y.; Li, T.; Zhang, B. Down-Regulation of miR-145 and miR-143 Might Be Associated with DNA Methyltransferase 3B Overexpression and Worse Prognosis in Endometrioid Carcinomas. Hum. Pathol. 2013, 44, 2571-2580. [CrossRef] [PubMed]

135. Chang, L.; Zhang, D.; Shi, H.; Bian, Y.; Guo, R. MiR-143 Inhibits Endometrial Cancer Cell Proliferation and Metastasis by Targeting MAPK1. Oncotarget 2017, 8, 84384-84395. [CrossRef]

136. Wu, Y.; Liu, S.; Xin, H.; Jiang, J.; Younglai, E.; Sun, S.; Wang, H. Up-Regulation of microRNA-145 Promotes Differentiation by Repressing OCT4 in Human Endometrial Adenocarcinoma Cells. Cancer 2011, 117, 3989-3998. [CrossRef]

137. Men, Y.; Zhang, L.; Ai, H. MicroRNA-145-5p Over-Expression Suppresses Proliferation, Migration and Invasion and Promotes B of Human Endometrial Cancer Cells by Tar-Geting Dual Specific Phosphatase 6. Nan Fang Yi Ke Da Xue Xue Bao 2020, 40, 61-66. (In Chinese) [CrossRef]

138. Qu, J.; Zhang, L.; Li, L.; Su, Y. miR-148b Functions as a Tumor Suppressor by Targeting Endoplasmic Reticulum Metallo Protease 1 in Human Endometrial Cancer Cells. Oncol. Res. Featur. Preclin. Clin. Cancer Ther. 2018, 27, 81-88. [CrossRef]

139. Li, B.; Lu, W.; Qu, J.; Ye, L.; Du, G.; Wan, X. Loss of Exosomal miR-148B from Cancer-Associated Fibroblasts Promotes Endometrial Cancer Cell Invasion and Cancer Metastasis. J. Cell. Physiol. 2019, 234, 2943-2953. [CrossRef]

140. Tsuruta, T.; Kozaki, K.-I.; Uesugi, A.; Furuta, M.; Hirasawa, A.; Imoto, I.; Susumu, N.; Aoki, D.; Inazawa, J. miR-152 Is a Tumor Suppressor microRNA That Is Silenced by DNA Hypermethylation in Endometrial Cancer. Cancer Res. 2011, 71, 6450-6462. [CrossRef]

141. Widodo; Djati, M.S.; Rifa'I, M. Role of MicroRNAs in Carcinogenesis That Potential for Biomarker of Endometrial Cancer. Ann. Med. Surg. 2016, 7, 9-13. [CrossRef]

142. Xie, D.; Liang, Y.; Su, Y.; An, Y.; Qu, P. miR-152 Inhibits Proliferation of Human Endometrial Cancer Cells via Inducing G2/M Phase Arrest by Suppressing CDC25B Expression. BioMed. Pharmacother. 2018, 99, 299-305. [CrossRef]

143. Choi, C.H.; Park, Y.-A.; Choi, J.-J.; Song, T.; Song, S.Y.; Lee, Y.-Y.; Lee, J.-W.; Kim, T.-J.; Kim, B.-G.; Bae, D.-S. Angiotensin II Type I Receptor and miR-155 in Endometrial Cancers: Synergistic Antiproliferative Effects of Anti-miR-155 and Losartan on Endometrial Cancer Cells. Gynecol. Oncol. 2012, 126, 124-131. [CrossRef] 
144. Wang, Z.-M.; Wan, X.-H.; Sang, G.-Y.; Zhao, J.-D.; Zhu, Q.-Y.; Wang, D.-M. miR-15a-5p Suppresses Endometrial Cancer Cell Growth via Wnt/ $\beta$-Catenin Signaling Pathway by Inhibiting WNT3A. Eur. Rev. Med. Pharmacol. Sci. 2017, 21, 4810-4818. [PubMed]

145. Devor, E.J.; Miecznikowski, J.; Schickling, B.M.; Gonzalez-Bosquet, J.; Lankes, H.A.; Thaker, P.; Argenta, P.A.; Pearl, M.L.; Zweizig, S.L.; Mannel, R.S.; et al. Dysregulation of miR-181c Expression Influences Recurrence of Endometrial Endometrioid Adenocarcinoma by Modulating NOTCH2 Expression: An NRG Oncology/Gynecologic Oncology Group study. Gynecol. Oncol. 2017, 147, 648-653. [CrossRef] [PubMed]

146. Zhuang, L.; Qu, H.; Cong, J.; Dai, H.; Liu, X. MiR-181c Affects Estrogen-Dependent Endometrial Carcinoma Cell Growth by Targeting PTEN. Endocr. J. 2019, 66, 523-533. [CrossRef]

147. Guo, Y.; Liao, Y.; Jia, C.; Ren, J.; Wang, J.; Li, T. MicroRNA-182 Promotes Tumor Cell Growth by Targeting Transcription Elongation Factor A-like 7 in Endometrial Carcinoma. Cell. Physiol. Biochem. 2013, 32, 581-590. [CrossRef]

148. Ruan, H.; Liang, X.; Zhao, W.; Ma, L.; Zhao, Y. The Effects of microRNA-183 Promots Cell Proliferation and Invasion by Targeting MMP-9 in Endometrial Cancer. BioMed. Pharmacother. 2017, 89, 812-818. [CrossRef]

149. Xiong, H.; Chen, R.; Liu, S.; Lin, Q.; Chen, H.; Jiang, Q. MicroRNA-183 Induces Epithelial-Mesenchymal Transition and Promotes Endometrial Cancer Cell Migration and Invasion in by Targeting CPEB1. J. Cell. Biochem. 2018, 119, 8123-8137. [CrossRef]

150. Yan, H.; Sun, B.; Zhang, Y.; Li, Y.; Huang, C.; Feng, F.; Li, C. Upregulation of miR-183-5p Is Responsible for the Promotion of Apoptosis and Inhibition of the Epithelial-Mesenchymal Transition, Proliferation, Invasion and Migration of Human Endometrial Cancer Cells by Downregulating Ezrin. Int. J. Mol. Med. 2018, 42, 2469-2480. [CrossRef]

151. Chen, Z.; Zhu, Y.; Fan, X.; Liu, Y.; Feng, Q. Decreased Expression of miR-184 Restrains the Growth and Invasion of Endometrial Carcinoma Cells through CDC25A-Dependent Notch Signaling Pathway. Am. J. Transl. Res. 2019, 11, 755-764.

152. Yang, C.; Ota-Kurogi, N.; Ikeda, K.; Okumura, T.; Horie-Inoue, K.; Takeda, S.; Inoue, S. MicroRNA-191 Regulates Endometrial Cancer Cell Growth via TET1-Mediated Epigenetic Modulation of APC. J. Biochem. 2020, 168, 7-14. [CrossRef]

153. Deng, J.; Wang, W.; Yu, G.; Ma, X. MicroRNA-195 Inhibits Epithelial Mesenchymal Transition by Targeting G Protein Coupled Estrogen Receptor 1 in Endometrial Carcinoma. Mol. Med. Rep. 2019, 20, 4023-4032. [CrossRef]

154. Zhao, X.; Dai, L.; Yue, Q.; Wang, H.; Wang, X.U.; Li, Y.; Chen, R. MiR-195 Inhibits Migration, Invasion and Epithelial-Mesenchymal Transition (EMT) of Endometrial Carcinoma Cells by Targeting SOX4. J. Biosci. 2019, 44, 146. [CrossRef] [PubMed]

155. Shi, W.; Wang, X.; Ruan, L.; Fu, J.; Liu, F.; Qu, J. MiR-200a Promotes Epithelial-Mesenchymal Transition of Endometrial Cancer Cells by Negatively Regulating FOXA2 Expression. Die Pharm. 2017, 72, 694-699.

156. Dai, Y.; Xia, W.; Song, T.; Su, X.; Li, J.; Li, S.; Chen, Y.; Wang, W.; Ding, H.; Liu, X.; et al. MicroRNA-200b Is Overexpressed in Endometrial Adenocarcinomas and EnhancesMMP2Activity by DownregulatingTIMP2in Human Endometrial Cancer Cell Line HEC-1A Cells. Nucleic Acid Ther. 2013, 23, 29-34. [CrossRef] [PubMed]

157. Park, Y.-A.; Lee, J.-W.; Choi, J.-J.; Jeon, H.-K.; Cho, Y.; Choi, C.; Kim, T.-J.; Lee, N.W.; Kim, B.-G.; Bae, D.-S. The Interactions between MicroRNA-200c and BRD7 in Endometrial Carcinoma. Gynecol. Oncol. 2012, 124, 125-133. [CrossRef]

158. Li, F.; Liang, A.; Lv, Y.; Liu, G.; Jiang, A.; Liu, P. MicroRNA-200c Inhibits Epithelial-Mesenchymal Transition by Targeting the BMI-1 Gene Through the Phospho-AKT Pathway in Endometrial Carcinoma Cells In Vitro. Med. Sci. Monit. 2017, 23, 5139-5149. [CrossRef]

159. Chen, R.; Zhang, M.; Liu, W.; Chen, H.; Cai, T.; Xiong, H.; Sheng, X.; Liu, S.; Peng, J.; Wang, F.; et al. Estrogen Affects the Negative Feedback Loop of PTENP1-miR200c to inhibit PTEN Expression in the Development of Endometrioid Endometrial Carcinoma. Cell Death Dis. 2018, 10, 4. [CrossRef]

160. Chen, P.; Xing, T.; Wang, Q.; Liu, A.; Liu, H.; Hu, Y.; Ji, Y.; Song, Y.; Wang, D. MicroRNA-202 Inhibits Cell Migration and Invasion through Targeting FGF2 and Inactivating Wnt/ $\beta$-Catenin Signaling in Endometrial Carcinoma. Biosci. Rep. 2019, 39, 20190680. [CrossRef]

161. Chung, T.; Lau, T.; Cheung, T.; Yim, S.; Lo, K.; Siu, N.; Chan, L.; Yu, M.; Kwong, J.; Doran, G.; et al. Dysregulation of microRNA-204 Mediates Migration and Invasion of Endometrial Cancer by Regulating FOXC1. Int. J. Cancer 2011, 130, 1036-1045. [CrossRef]

162. Bao, W.; Wang, H.-H.; Tian, F.-J.; He, X.-Y.; Qiu, M.-T.; Wang, J.-Y.; Zhang, H.-J.; Wang, L.-H.; Wan, X.-P. A TrkB-STAT3-miR-204-5p Regulatory Circuitry Controls Proliferation and Invasion of Endometrial Carcinoma Cells. Mol. Cancer 2013, 12, 155. [CrossRef]

163. Guo, S.; Yang, J.; Wu, M.; Xiao, G. Clinical Value Screening, Prognostic Significance and Key Pathway Identification of miR-204-5p in Endometrial Carcinoma: A study based on the Cancer Genome Atlas (TCGA), and bioinformatics analysis. Pathol. Res. Pr. 2019, 215, 1003-1011. [CrossRef]

164. Su, N.; Qiu, H.; Chen, Y.; Yang, T.; Yan, Q.; Wan, X. miR-205 Promotes Tumor Proliferation and Invasion through Targeting ESRRG in Endometrial Carcinoma. Oncol. Rep. 2013, 29, 2297-2302. [CrossRef]

165. Zhang, G.; Hou, X.; Li, Y.; Zhao, M. MiR-205 Inhibits Cell Apoptosis by Targeting Phosphatase and Tensin Homolog Deleted on Chromosome Ten in Endometrial Cancer Ishikawa Cells. BMC Cancer 2014, 14, 440. [CrossRef]

166. Ma, Y.-J.; Ha, C.-F.; Bai, Z.-M.; Li, H.-N.; Xiong, Y.; Jiang, J. Overexpression of microRNA-205 Predicts Lymph Node Metastasis and Indicates an Unfavorable Prognosis in Endometrial Cancer. Oncol. Lett. 2016, 12, 4403-4410. [CrossRef]

167. Zhuo, Z.; Yu, H. miR-205 Inhibits Cell Growth by Targeting AKT-mTOR Signaling in Progesterone-Resistant Endometrial Cancer Ishikawa Cells. Oncotarget 2017, 8, 28042-28051. [CrossRef]

168. Jin, C.; Liang, R. miR-205 Promotes Epithelial-Mesenchymal Transition by Targeting AKT Signaling in Endometrial Cancer Cells. J. Obstet. Gynaecol. Res. 2015, 41, 1653-1660. [CrossRef] 
169. Zheng, Y.; Yang, X.; Wang, C.; Zhang, S.; Wang, Z.; Li, M.; Wang, Y.; Wang, X.; Yang, X. HDAC6, modulated by miR-206, Promotes Endometrial Cancer Progression through the PTEN/AKT/mTOR Pathway. Sci. Rep. 2020, 10, 1-12. [CrossRef]

170. Wang, C.; Li, Q.; He, Y. MicroRNA-21-5p Promotes Epithelial to Mesenchymal Transition by Targeting SRY-box 17 in Endometrial Cancer. Oncol. Rep. 2020, 43, 1897-1905. [CrossRef]

171. Gao, X.; Cai, Y.; An, R. miR-215 Promotes Epithelial to Mesenchymal Transition and Proliferation by Regulating LEFTY2 in Endometrial Cancer. Int. J. Mol. Med. 2018, 42, 1229-1236. [CrossRef]

172. Li, X.-C.; Hai, J.-J.; Tan, Y.-J.; Yue, Q.-F.; Liu, L.-J. MiR-218 Suppresses Metastasis and Invasion of Endometrial Cancer via Negatively Regulating ADD2. Eur. Rev. Med. Pharmacol. Sci. 2019, 23, 1408-1417.

173. Liu, B.; Che, Q.; Qiu, H.; Bao, W.; Chen, X.; Lu, W.; Li, B.; Wan, X. Elevated MiR-222-3p Promotes Proliferation and Invasion of Endometrial Carcinoma via Targeting ER $\alpha$. PLoS ONE 2014, 9, e87563. [CrossRef]

174. Huang, K.; Dong, X.; Sui, C.; Hu, D.; Xiong, T.; Liao, S.; Zhang, H. MiR-223 Suppresses Endometrial Carcinoma Cells Prolif-eration by Targeting IGF-1R. Am. J. Transl. Res. 2014, 6, 841-849. [PubMed]

175. Jiang, F.-Z.; He, Y.-Y.; Wang, H.-H.; Zhang, H.-L.; Zhang, J.; Yan, X.-F.; Wang, X.-J.; Che, Q.; Ke, J.-Q.; Chen, Z.; et al. Mutant p53 Induces EZH2 Expression and Promotes Epithelial-Mesenchymal Transition by Disrupting p68-Drosha Complex Assembly and Attenuating MiR-26a Processing. Oncotarget 2015, 6, 44660-44674. [CrossRef] [PubMed]

176. Che, X.; Jian, F.; Chen, C.; Liu, C.; Liu, G.; Feng, W. PCOS Serum-Derived Exosomal miR-27a-5p Stimulates Endometrial Cancer Cells Migration and Invasion. J. Mol. Endocrinol. 2020, 64, 1-12. [CrossRef] [PubMed]

177. Liu, L.; Hu, J.; Yu, T.; You, S.; Zhang, Y.; Hu, L. miR-27b-3p/MARCH7 Regulates Invasion and Metastasis of Endometrial Cancer Cells through Snail-Mediated Pathway. Acta Biochim. Biophys. Sin. 2019, 51, 492-500. [CrossRef]

178. Jiang, T.; Sui, D.; You, D.; Yao, S.; Zhang, L.; Wang, Y.; Zhao, J.; Zhang, Y. MiR-29a-5p Inhibits Proliferation and Invasion and Induces Apoptosis in Endometrial Carcinoma via Targeting TPX2. Cell Cycle 2018, 17, 1268-1278. [CrossRef]

179. Kong, J.; He, X.; Wang, Y.; Li, J. Effect of microRNA-29b on Proliferation, Migration, and Invasion of Endometrial Cancer Cells. J. Int. Med. Res. 2019, 47, 3803-3817. [CrossRef]

180. Chen, H.-X.; Xu, X.-X.; Tan, B.-Z.; Zhang, Z.; Zhou, X.-D. MicroRNA-29b Inhibits Angiogenesis by Targeting VEGFA through the MAPK/ERK and PI3K/Akt Signaling Pathways in Endometrial Carcinoma. Cell. Physiol. Biochem. 2017, 41, 933-946. [CrossRef]

181. Li, L.; Shou, H.; Wang, Q.; Liu, S. Investigation of the Potential Theranostic Role of KDM5B/miR-29c Signaling Axis in Paclitaxel Resistant Endometrial Carcinoma. Gene 2019, 694, 76-82. [CrossRef]

182. Ma, J.; Li, D.; Kong, F.-F.; Yang, D.; Yang, H.; Ma, X.-X. miR-302a-5p/367-3p-HMGA2 Axis Regulates Malignant Processes during Endometrial Cancer Development. J. Exp. Clin. Cancer Res. 2018, 37, 19. [CrossRef]

183. Hu, Y.; Zhou, H.; Xu, X.; Xun, Q.; Yu, D.; Ling, J.; Guo, F.; Yan, Y.; Shi, J. microRNA-30c Negatively Regulates Endometrial Cancer Cells by Targeting Metastasis-Associated Gene-1. Oncol. Rep. 2011, 27, 807-812. [CrossRef]

184. Kong, X.; Xu, X.; Yan, Y.; Guo, F.; Li, J.; Hu, Y.; Zhou, H.; Xun, Q. Estrogen Regulates the Tumour Suppressor MiRNA-30c and Its Target Gene, MTA-1, in Endometrial Cancer. PLoS ONE 2014, 9, e90810. [CrossRef]

185. Xu, X.; Kong, X.; Liu, T.; Zhou, L.; Wu, J.; Fu, J.; Wang, Y.; Zhu, M.; Yao, S.; Ding, Y.; et al. Metastasis-Associated Protein 1, Modulated by miR-30c, Promotes Endometrial Cancer Progression through AKT/mTOR/4E-BP1 Pathway. Gynecol. Oncol. 2019, 154, 207-217. [CrossRef]

186. Shu, S.; Liu, X.; Xu, M.; Gao, X.; Chen, S.; Zhang, L.; Li, R. MicroRNA-320a Acts as a Tumor Suppressor in Endometrial Carcinoma by Targeting IGF-1R. Int. J. Mol. Med. 2019, 43, 1505-1512. [CrossRef]

187. Zhang, H.; Li, R.; Li, Y.; Yu, X.; Sun, Q.; Li, A.; Kong, Y. eIF4E-Related miR-320a and miR-340-5p Inhibit Endometrial Carcinoma Cell Metastatic Capability by Preventing TGF- $\beta 1-I n d u c e d$ Epithelial Mesenchymal Transition. Oncol. Rep. 2019, 43, 447-460. [CrossRef]

188. Liu, W.; Zhang, B.; Xu, N.; Wang, M.-J.; Liu, Q. miR-326 Regulates EMT and Metastasis of Endometrial Cancer through Targeting TWIST1. Eur. Rev. Med. Pharmacol. Sci. 2017, 21, 3787-3793.

189. Gao, Y.; Qian, H.; Tang, X.; Du, X.; Wang, G.; Zhang, H.; Ye, F.; Liu, T. Superparamagnetic Iron Oxide Nanoparticle-Mediated Expression of miR-326 Inhibits Human Endometrial Carcinoma Stem Cell Growth. Int. J. NanoMed. 2019, ume 14, $2719-2731$ [CrossRef]

190. Dou, X.; Chen, X.; Zhou, Q.; Wen, M.; Zhang, S.; Zhang, S. miR-335 Modulates Numb Alternative Splicing via Targeting RBM10 in Endometrial Cancer. Kaohsiung J. Med. Sci. 2020, 36, 171-177. [CrossRef]

191. Xie, W.; Qin, W.; Kang, Y.; Zhou, Z.; Qin, A. MicroRNA-340 Inhibits Tumor Cell Proliferation and Induces Apoptosis in Endometrial Carcinoma Cell Line RL 95-2. Med. Sci. Monit. 2016, 22, 1540-1546. [CrossRef]

192. Schirmer, U.; Doberstein, K.; Rupp, A.-K.; Bretz, N.P.; Wuttig, D.; Kiefel, H.; Breunig, C.; Fiegl, H.; Müller-Holzner, E.; Zeillinger, R.; et al. Role of miR-34a as a Suppressor of L1CAM in Endometrial Carcinoma. Oncotarget 2014, 5, 462-472. [CrossRef]

193. Choi, Y.S.; Lee, K.E. The Significance of miR-34a Expression in Endometrial Carcinogenesis: Correlation With Expression of p16 and Ki-67 Proteins in Endometrial Cancers. J. Cancer Prev. 2015, 20, 268-274. [CrossRef]

194. Wang, Z.; Wang, W.; Huang, K.; Wang, Y.; Li, J.; Yang, X. MicroRNA-34a Inhibits Cells Proliferation and Invasion by Downregulating Notch1 in Endometrial Cancer. Oncotarget 2017, 8, 111258-111270. [CrossRef] [PubMed]

195. Jiang, L.; Meng, W.; Zeng, J.; Hu, H.; Lu, L. MiR-34c Oligonucleotide Enhances Chemosensitivity of Ishikawa Cell to Cisplatin by Inducing Apoptosis. Cell Biol. Int. 2013, 37, 577-583. [CrossRef] [PubMed] 
196. Li, F.; Chen, H.; Huang, Y.; Zhang, Q.; Xue, J.; Liu, Z.; Zheng, F. miR-34c Plays a Role of Tumor Suppressor in HEC-1-B Cells by Targeting E2F3 Protein. Oncol. Rep. 2015, 33, 3069-3074. [CrossRef]

197. Liu, B.-L.; Sun, K.-X.; Zong, Z.-H.; Chen, S.; Zhao, Y. MicroRNA-372 Inhibits Endometrial Carcinoma Development by Targeting the Expression of the Ras Homolog Gene Family Member C (RhoC). Oncotarget 2016, 7, 6649-6664. [CrossRef] [PubMed]

198. Li, Y.; Sun, D.; Gao, J.; Shi, Z.; Chi, P.; Meng, Y.; Zou, C.; Wang, Y. MicroRNA-373 Promotes the Development of Endometrial Cancer by Targeting LATS2 and activating the Wnt/ $\beta$-Catenin Pathway. J. Cell. Biochem. 2019, 120, 8611-8618. [CrossRef] [PubMed]

199. Tu, C.; Wang, F.; Wan, J. MicroRNA-381 Inhibits Cell Proliferation and Invasion in Endometrial Carcinoma by Targeting the IGF-1R. Mol. Med. Rep. 2017, 17, 4090-4098. [CrossRef]

200. Zhang, C.; Wang, B.; Wu, L. MicroRNA-409 May Function as a Tumor Suppressor in Endometrial Carcinoma Cells by Targeting Smad2. Mol. Med. Rep. 2018, 19, 622-628. [CrossRef]

201. Li, Q.; Qiu, X.-M.; Li, Q.-H.; Wang, X.-Y.; Li, L.; Xu, M.; Dong, M.; Xiao, Y.-B. MicroRNA-424 May Function as a Tumor Suppressor in Endometrial Carcinoma Cells by Targeting E2F7. Oncol. Rep. 2015, 33, 2354-2360. [CrossRef]

202. Zhang, H.; Wang, X.; Chen, Z.; Wang, W. MicroRNA-424 Suppresses Estradiol-Induced Cell Proliferation via Targeting GPER in Endometrial Cancer Cells. Cell. Mol. Biol. 2015, 61, 96-101.

203. Shu, S.; Liu, X.; Xu, M.; Gao, X.; Fan, J.; Liu, H.; Li, R. MicroRNA-424 Regulates Epithelial-Mesenchymal Transition of Endometrial Carcinoma by Directly Targeting Insulin-like Growth Factor 1 Receptor. J. Cell. Biochem. 2019, 120, 2171-2179. [CrossRef]

204. Lu, K.; Lin, J.; Jiang, J. Osthole Inhibited Cell Proliferation and Induced Cell Apoptosis through Decreasing CPEB2 Expression via Up-regulating miR-424 in Endometrial Carcinoma. J. Recept. Signal Transduct. 2020, 40, 89-96. [CrossRef]

205. Ye, W.; Xue, J.; Zhang, Q.; Li, F.; Zhang, W.; Chen, H.; Huang, Y.; Zheng, F. MiR-449a Functions as a Tumor Suppressor in Endometrial Cancer by Targeting CDC25A. Oncol. Rep. 2014, 32, 1193-1199. [CrossRef]

206. Hu, Y.; Wu, A.-Y.; Xu, C.; Song, K.-Q.; Wang, W.-J.; Yin, X.; Di, W.; Hong, Z.-B.; Qiu, L.-H. MicroRNA-449a Inhibits Tumor Metastasis through AKT/ERK1/2 Inactivation by Targeting Steroid Receptor Coactivator (SRC) in Endometrial Cancer. J. Cancer 2019, 10, 547-555. [CrossRef]

207. Wu, A.-Y.; Hu, Y.; Cang, W.; Li, D.; Wang, W.-J.; Tian, Q.; Gu, L.-Y.; Zhang, N.; Ji, F.; Qiu, L.-H. Suppressive effect of microRNA449a on the NDRG1/PTEN/AKT Axis Regulates Endometrial Cancer Growth and Metastasis. Exp. Cell Res. 2019, $382,111468$. [CrossRef]

208. Zhu, L.; Wang, X.; Wang, T.; Zhu, W.; Zhou, X. miR-494-3p Promotes the Progression of Endometrial Cancer by Regulating the PTEN/PI3K/AKT pathway. Mol. Med. Rep. 2018, 19, 581-588. [CrossRef]

209. Tan, A.; Luo, R.; Ruan, P. miR-495 Promotes Apoptosis and Inhibits Proliferation in Endometrial Cells via Targeting PIK3R1. Pathol. Res. Pr. 2019, 215, 594-599. [CrossRef]

210. Chen, S.; Sun, K.-X.; Liu, B.-L.; Zong, Z.-H.; Zhao, Y. MicroRNA-505 Functions as a Tumor Suppressor in Endometrial Cancer by Targeting TGF- $\alpha$. Mol. Cancer 2016, 15, 11. [CrossRef]

211. Zhang, H.; Han, Y.; Zhang, X.; Xiao, N.; Jiang, T.; Zhu, S.; Wang, E.; Chen, C. miR-522 Facilitates the Prosperities of Endometrial Carcinoma Cells by Directly Binding to Monoamine Oxidase B. Kaohsiung J. Med. Sci. 2019, 35, 598-606. [CrossRef]

212. Bing, L.; Hong, C.; Li-Xin, S.; Wei, G. MicroRNA-543 Suppresses Endometrial Cancer Oncogenicity via Targeting FAK and TWIST1 Expression. Arch. Gynecol. Obstet. 2014, 290, 533-541. [CrossRef]

213. Wang, Y.; Dong, L.; Liu, Y. Targeting Thyroid Receptor Interacting Protein 6 by MicroRNA-589-5p Inhibits Cell Proliferation, Migration, and Invasion in Endometrial Carcinoma. Cancer Biother. Radiopharm 2019, 34, 529-536. [CrossRef]

214. Sun, X.; Dongol, S.; Qiu, C.; Xu, Y.; Sun, C.; Zhang, Z.; Yang, X.; Zhang, Q.; Kong, B. miR-652 Promotes Tumor Proliferation and Metastasis by Targeting RORA in Endometrial Cancer. Mol. Cancer Res. 2018, 16, 1927-1939. [CrossRef] [PubMed]

215. Chen, S.; Chen, X.; Sun, K.-X.; Xiu, Y.-L.; Liu, B.-L.; Feng, M.-X.; Sang, X.-B.; Zhao, Y. MicroRNA-93 Promotes EpithelialMesenchymal Transition of Endometrial Carcinoma Cells. PLoS ONE 2016, 11, e0165776. [CrossRef] [PubMed]

216. Gao, Y.; Deng, K.; Liu, X.; Dai, M.; Chen, X.; Chen, J.; Chen, J.; Huang, Y.; Dai, S.; Chen, J. Molecular Mechanism and Role of microRNA-93 in Human Cancers: A Study Based on Bioinformatics Analysis, Meta-Analysis, and Quantitative Polymerase Chain Reaction Validation. J. Cell. Biochem. 2019, 120, 6370-6383. [CrossRef] [PubMed]

217. Xu, J.-B. MicroRNA-93-5p/IFNAR1 Axis Accelerates Metastasis of Endometrial Carcinoma by Activating the STAT3 Pathway. Eur. Rev. Med. Pharmacol. Sci 2019, 23, 5657-5666. [PubMed]

218. Zhou, Z.; Xu, Y.-P.; Wang, L.-J.; Kong, Y. miR-940 Potentially Promotes Proliferation and Metastasis of Endometrial Carcinoma through Regulation of MRVI1. Biosci. Rep. 2019, 39, 20190077. [CrossRef] [PubMed]

219. He, Z.; Xu, H.; Meng, Y.; Kuang, Y. miR-944 Acts as a Prognostic Marker and Promotes the Tumor Progression in Endometrial Cancer. BioMed. Pharmacother. 2017, 88, 902-910. [CrossRef]

220. Li, Y.; Zhang, Z.; Zhang, X.; Lin, Y.; Luo, T.; Xiao, Z.; Zhou, Q. A dual PI3K/AKT/mTOR Signaling Inhibitor miR-99a Suppresses Endometrial Carcinoma. Am. J. Transl. Res. 2016, 8, 719-731.

221. Ala, U. Competing Endogenous RNAs, Non-Coding RNAs and Diseases: An Intertwined Story. Cells 2020, 9, 1574. [CrossRef]

222. Lou, W.; Ding, B.; Fu, P. Pseudogene-Derived lncRNAs and Their miRNA Sponging Mechanism in Human Cancer. Front. Cell Dev. Biol. 2020, 8, 85. [CrossRef]

223. Kumar, S.; Cheng, X.; Klimasauskas, S.; Sha, M.; Posfai, J.; Roberts, R.J.; Wilson, G.G. The DNA (cytosine-5) Methyltransferases. Nucleic Acids Res. 1994, 22, 1-10. [CrossRef] 
224. Deaton, A.M.; Bird, A. CpG Islands and the Regulation of Transcription. Genes Dev. 2011, 25, 1010-1022. [CrossRef]

225. Jones, P.A. Functions of DNA Methylation: Islands, Start Sites, Gene Bodies and Beyond. Nat. Rev. Genet. 2012, 13, 484-492. [CrossRef]

226. Zhang, J.; Yang, C.; Wu, C.; Cui, W.; Wang, L. DNA Methyltransferases in Cancer: Biology, Paradox, Aberrations, and Targeted Therapy. Cancers 2020, 12, 2123. [CrossRef]

227. Ghabreau, L.; Roux, J.P.; Niveleau, A.; Mokni, M.; Frappart, L. Correlation between the DNA Global Methylation Status and Progesterone Receptor Expression in Normal Endometrium, Endometrioid Adenocarcinoma and Precursors. Virchows Arch. 2004, 445, 129-134. [CrossRef]

228. Berger, S.L. The Complex Language of Chromatin Regulation during Transcription. Nat. Cell Biol. 2007, 447, 407-412. [CrossRef]

229. Kouzarides, T. Chromatin Modifications and Their Function. Cell 2007, 128, 693-705. [CrossRef]

230. Flaus, A.; Downs, J.A.; Owen-Hughes, T. Histone Isoforms and the Oncohistone Code. Curr. Opin. Genet. Dev. 2021, 67, 61-66. [CrossRef]

231. Zhou, M.; Zhang, Z.; Zhao, H.; Bao, S.; Sun, J. A Novel lncRNA-Focus Expression Signature for Survival Prediction in Endometrial Carcinoma. BMC Cancer 2018, 18, 39. [CrossRef]

232. Ouyang, D.; Li, R.; Li, Y.; Zhu, X. A 7-lncRNA Signature Predict Prognosis of Uterine Corpus Endometrial Carcinoma. J. Cell. Biochem. 2019, 120, 18465-18477. [CrossRef]

233. Tang, H.; Wu, Z.; Zhang, Y.; Xia, T.; Liu, D.; Cai, J.; Ye, Q. Identification and Function Analysis of a Five-Long Noncoding RNA Prognostic Signature for Endometrial Cancer Patients. DNA Cell Biol. 2019, 38, 1480-1498. [CrossRef]

234. Wang, P.; Zeng, Z.; Shen, X.; Tian, X.; Ye, Q. Identification of a Multi-RNA-Type-Based Signature for Recurrence-Free Survival Prediction in Patients with Uterine Corpus Endometrial Carcinoma. DNA Cell Biol. 2020, 39, 615-630. [CrossRef]

235. Zeng, Z.; Cheng, J.; Ye, Q.; Zhang, Y.; Shen, X.; Cai, J.; Li, M. A 14-Methylation-Driven Differentially Expressed RNA as a Signature for Overall Survival Prediction in Patients with Uterine Corpus Endometrial Carcinoma. DNA Cell Biol. 2020, 39, 975-991. [CrossRef]

236. Ahsen, M.E.; Boren, T.P.; Singh, N.K.; Misganaw, B.; Mutch, D.G.; Moore, K.N.; Backes, F.J.; McCourt, C.K.; Lea, J.S.; Miller, D.S.; et al. Sparse Feature Selection for Classification and Prediction of Metastasis in Endometrial Cancer. BMC Genom. 2017, 18, 233. [CrossRef]

237. Rai, R.; Fatima, I.; Essel, K.; Chandra, V. Molecular Diagnosis of Uterine Cancer. In Molecular Diagnostics in Cancer Patients; Shukla, K.K., Sharma, P., Misra, S., Eds.; Springer: Singapore, 2019; pp. 305-321, ISBN 9789811358760.

238. Gulìa, C.; Signore, F.; Gaffi, M.; Gigli, S.; Votino, R.; Nucciotti, R.; Bertacca, L.; Zaami, S.; Baffa, A.; Santini, E.; et al. Y RNA: An Overview of Their Role as Potential Biomarkers and Molecular Targets in Human Cancers. Cancers 2020, 12, 1238. [CrossRef] 